\title{
A preserved early Ediacaran magmatic arc at the northernmost portion of the Transversal Zone central subprovince of the Borborema Province, Northeastern South America
}

\author{
Arco magmático eoediacarano na porção setentrional da Zona \\ Transversal, sub-província central da Província Borborema, \\ nordeste da América do Sul
}

\author{
Benjamim Bley de Brito Neves ${ }^{1 *}$, Edilton José dos Santos ${ }^{2}$, \\ Reinhardt Adolfo Fuck ${ }^{3}$, Lauro César Montefalco Lira Santos ${ }^{4}$
}

\begin{abstract}
Magmatic arcs are an essential part of crust-forming events in planet Earth evolution. The aim of this work was to describe an early Ediacaran magmatic arc (ca. 635-580 Ma) exposed in the northernmost portion of the Transversal Zone, central subprovince of Borborema Province, northeast Brazil. Our research took advantage of several syntheses by different authors, including theses and dissertations, carried out on magmatic rocks of the study area for the last 30 years. The ca. $750 \mathrm{~km}$ long and up to $140 \mathrm{~km}$ wide arc, trending ENE-WSW, is preserved to the south of the Patos Lineament, between $35^{\circ} 15^{\prime}$ and $42^{\circ} 30^{\circ} \mathrm{W}$ and $7{ }^{\circ} 15^{\prime}$ and $8^{\circ} \mathrm{S}$. About 90 different stocks and batholiths of I-type granitic rocks were mapped along this orogenic zone, preferentially intruding low-grade schists of the Cryogenian-Ediacaran Piancó-Alto Brígida (SPAB) belt. Three igneous supersuites are recognized: a) epidote-bearing granodiorites and tonalites ("Conceiçâa" type); b) high-K calc-alkaline granites ("Itaporanga" type); c) biotite granodiorites of trondhjemite affinity ("Serrita" type). A fourth group of peralkalic and shoshonitic rocks occurs to the south of the previous ones, reflecting special tectonic conditions. NNE-SSW trending Paleoproterozoic fold belts, surrounding Archean nuclei, characterize the continental part of the northern lower plate. The oceanic fraction of this lower plate was recycled by subduction and scarce remnants of which may be seen either within the enclosing low-grade schists or as xenoliths within the arc intrusions. The upper continental plate presents WSW-ENE structural trends and is composed of Neoproterozoic fold belts and Paleoproterozoic reworked basement inliers. Available data bear clear evidence of an Ediacaran magmatic arc built at the northern portion of the Transversal Zone in the Borborema Province, northeast Brazil.
\end{abstract}

KEYWORDS: Borborema Province; Transversal zone; Magmatic arc; Epidote-bearing granodiorites and tonalites; Continental boundary transform.
RESUMO: $O$ objetivo deste trabalho é introduzir o conceito de um arco magmático eoediacarano (ca. 635-580 Ma) na porção norte da zona transversal, subprovincia central da Provincia Borborema. Nossas pesquisas foram beneficiadas pela preexistência de sinteses de diferentes autores, incluindo teses e dissertaçóes, sobre a zona transversal nos últimos 30 anos. $O$ arco proposto está situado entre $35^{\circ} 15^{\circ} \mathrm{W}$ e $42^{\circ} 30^{\prime} \mathrm{W}$ (extensäo ca. $750 \mathrm{~km}$ ) e 7015'S e $8^{\circ} \mathrm{S}$ (largura de até $140 \mathrm{~km}$ ), segundo trend geral NNE-SSW, ao sul do Lineamento Patos. Cerca de 90 stocks e batólitos graniticos tipo I foram reconhecidos e mapeados ao longo da zona acrescionária. Essas rochas intrudem preferencialmente xistos de médio e baixo grau da Faixa Orogênica Piancó-Alto Brígida (SPAB) do Criogeniano-Ediacarano. Três supersuites igneas são reconhecidas: a) granodioritos e tonalitos a epídoto (tipo Conceição); b) granitos calcioalcalinos de alto K (tipo Itaporanga); c) biotita granodioritos de afinidade trondhjemitica (tipo Serrita). O quarto grupo de rochas igneas peralcalinas e shoshoniticas ocorre ao sul dos anteriores, refletindo especiais condiçôes tectônicas locais. A parte continental da placa inferior (ao norte do Lineamento Patos) é caracterizada por faixas móveis paleoproterozoicas, circunscrevendo alguns núcleos arqueanos. A fração oceânica dessa placa inferior foi completamente reciclada por subducção para o sul, embora escassos remanescentes sejam reconhecidos entre os xistos de baixo grau e como xenólitos das intrusóes magmáticas. A parte continental da placa superior apresenta trend estrutural WSW-ENE e é composta de faixas orogênicas neoproterozoicas, com alguns remanescentes paleoproterozoicos de embasamento retrabalhado.

PALAVRAS-CHAVE: Provincia Borborema; Zona transversal; Arco magmático; Granodioritos e tonalitos a epídoto; Transformante intracontinental de borda de placa.

\footnotetext{
${ }^{1}$ Full Professor, Instituto de Geociências, Universidade de São Paulo - USP, São Paulo (SP), Brazil. E-mail: bbleybn@usp.br ${ }^{2}$ Senior Geologist, Brazilian Geological Survey, Recife (PE), Brazil. E-mail: edilton.santos@cprm.gov.br

${ }^{3}$ Emeritus Professor, Instituto Geociências, Universidade de Brasília - UNB, Brasília (DF), Brazil. E-mail: reinhardt@unb.br

${ }^{4}$ Assistant Professor, Universidade Federal de Campina Grande - UFCG, Campina Grande (PB), Brazil. E-mail: lauromontefalco@gmail.com

*Corresponding author.

Manuscript ID: 20160004. Received in: 01/07/2016. Approved in: 10/24/2016
} 


\section{INTRODUCTION}

The Borborema Province, in northeastern South America, comprises a branching system of Neoproterozoic orogens (Fig. 1). These orogens, before Pangea breakup, can be traced into Africa, between Ghana, in the north, and Cameroon, in the south. Thus, the province lies between the West AfricaSão Luis craton to the north, the São Francisco-Congo-KasaiAngola craton to the south, and the Parnaíba block to the west, the latter concealed beneath Parnaíba Basin. At least in the former case of two cratonic domains, there is concrete evidence that were fractions of lithospheric plates, which developed via subduction-like processes within the interior of the surrounding folded systems (Santos et al. 2009, Oliveira et al. 2010, among others), and thus participated in the formation of the fold belts. The fact that the province is bordered by large cratons does not obscure the equally important participation of a few basement segments, perhaps even microcontinents and microplates, within the complex mosaic of the fold-system interior. Alternating basement inliers and fold belts is the characteristic feature of this branching system of Borborema Province (Santos \& Brito Neves 1984, Santos et al. 1984).

The basement of the orogenic system is also branched, comprising the Archean nuclei, surrounded by Paleoproterozoic mobile belts (mainly Rhyacian and Orosirian in age), and also early Neoproterozoic orogens related to the Tonian Cariris Velhos orogeny, all of which were thoroughly reworked in the late Neoproterozoic. Consequently, the different Neoproterozoic orogenic belts are separated by varied pre-Mesoproterozoic basement segments, which may also be exposed within the Neoproterozoic belts.

Referred to as massifs or terranes, these inliers may have acted in different ways in the Pre-orogenic history of the

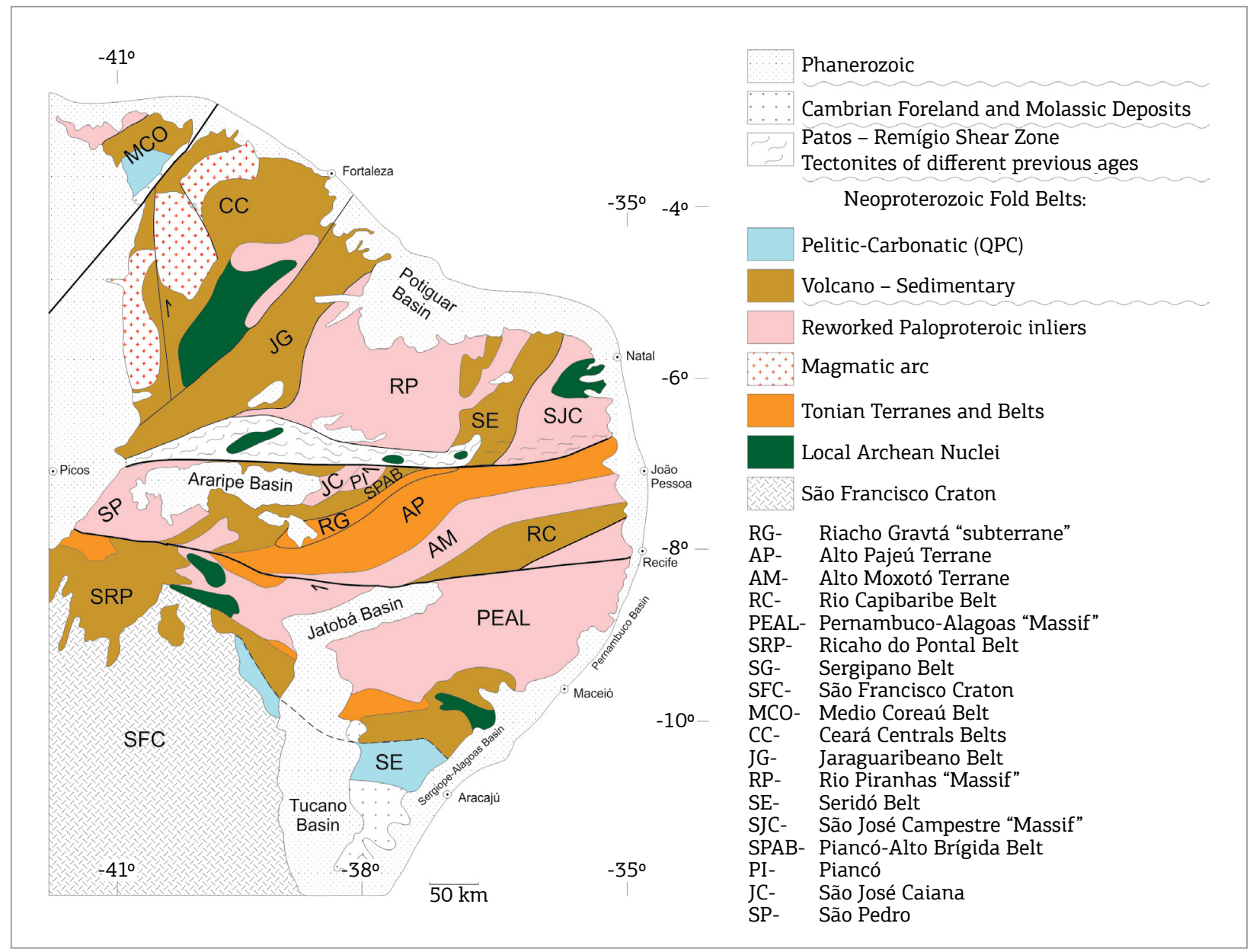

Figure 1. Sketch of the main tectonic elements of the Borborema Province (mostly based on previous schemes by Brito Neves et al. 2000, Oliveira 2008, Brito Neves et al. 2015b), displaying: (A) Northwest of the province (Médio Coreaú - MCO), to the west of Kandi-Transbrasiliano Lineament; (B) northern domains, north of the Patos Lineament (Ceará Central, Orós-Jaguaribe, Rio Grande do Norte terranes); (C) central subprovince - Transversal Zone, between Patos (LPT) and Pernambuco (LPE) lineaments; (D) southern subprovince, comprising PernambucoAlagoas (PEAL) superterrane and the belts marginal to the northern periphery of São Francisco Craton (SFC): Sergipano (SE), Riacho do Pontal (SRP) and Rio Preto (RP). 
branching system. As mentioned in the passage before, it is possible that some of the inliers behaved as microcontinents, or even as microplates, separating distinct parts of the orogenic belts. On the other hand, some of the inliers are just the exposure of the basement of the orogenic pile. Future research relying on geophysical data and/or deep boreholes should be able to discriminate these possibilities.

The orogenic belts of the province fan out along structural lines that strike perpendicular to the coast, from the NE-SW Médio Coreaú domain, northwestward, to NW-SE Sergipano Belt, southeastward (Fig. 1). The Neoproterozoic belts bear distinct characteristics in composition, evolution, and preservation from superposed exhumation processes. Some are well preserved orogenic belts, displaying substantial parts of their lithostratigraphic, collisional and/or accretionary records. Other ones are vestigial belts ("schist belts"), in the sense that very little of their original orogenic record is preserved. Recently, several features of accretionary orogenies were recognized within the collisional domains related to the Neoproterozoic history of the province (Figs. 1 and 2), from NW Ceará (Fetter et al. 2003, Santos et al. 2009, 2015, Cordani et al. 2013, among others) to the SE of the province (Oliveira et al. 2010, among others). However, in the central part of the province, the record of arc magmatism is less obvious and has led to a long-lasting debate.

The E-W Patos and Pernambuco strike-slip lineaments, to the north and south, respectively, limit the central domain of the province; this is the so-called Transversal Zone, which separates rather different geologic-geotectonic domains. The northern Patos lineament (Archanjo et al. 2013) has particularly been recognized as a continental transform (Brito Neves et al. 2015a), dividing distinct lithospheric domains of the province, which differ in composition, age, structure and thickness, and are displaced laterally for more than $100 \mathrm{~km}$.

In this work, we aimed to characterize the preserved accretionary belt exposed in the northern part of the Transversal

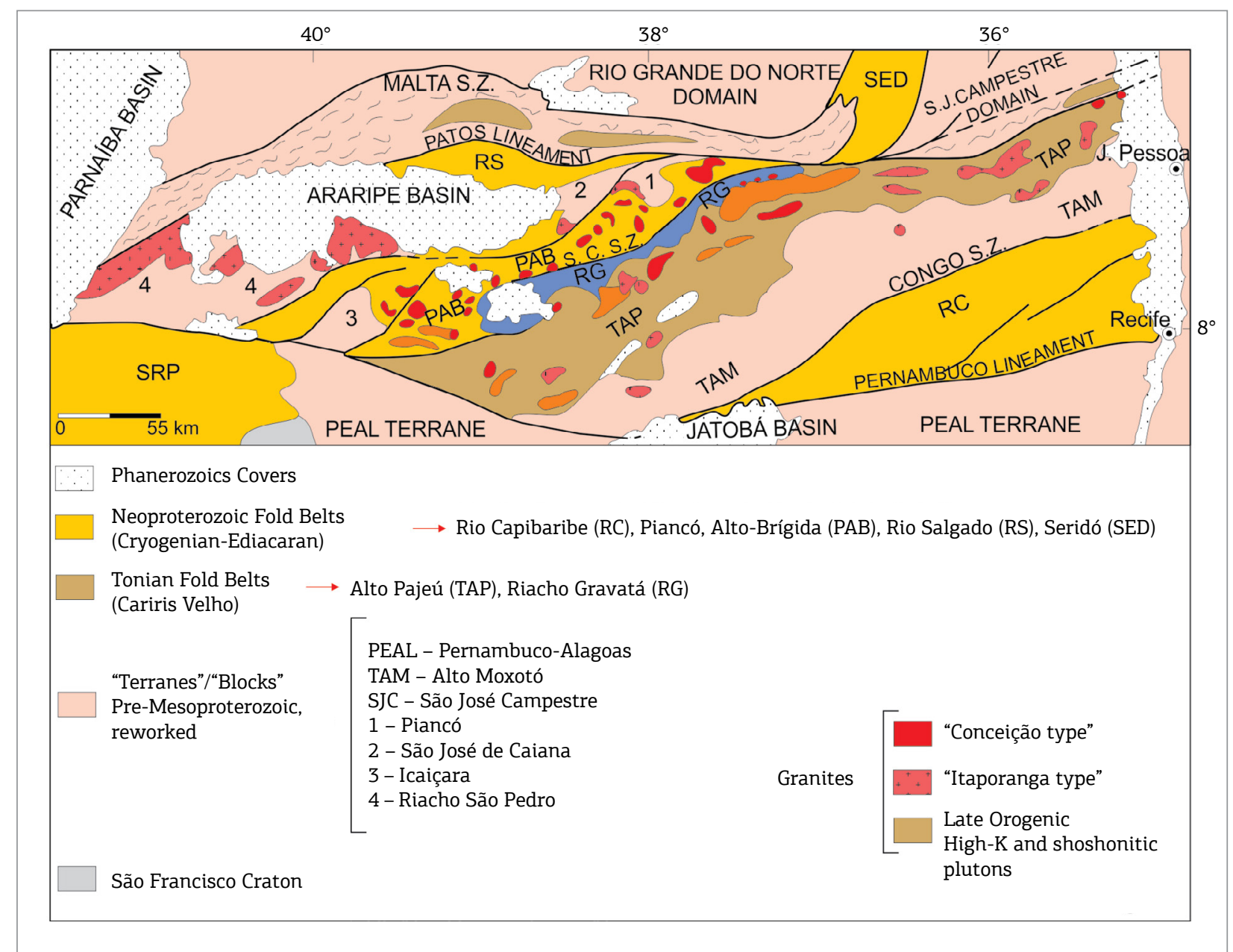

Figure 2. Sketch of the Transversal Zone and surroundings based on recent maps and authors, showing the main basement inliers (terranes) and Neoproterozoic fold belts and intrusions (Tabs. 1 and 2), considered as the main elements of an Early Ediacaran magmatic arc. Note the shear zone to the north, related to the Patos Lineament (keirogen). The Pernambuco-Alagoas superterrane, part of the Riacho do Pontal fold system and a small fraction of the northern São Francisco Craton are located to the south of the Pernambuco Lineament. 
Zone (the central subprovince) (Van Schmus et al. 2011). Abundant references are available on this particular area of the province, largely mapped at different scales and studied through academic work, which brought about a wealth of petrologic, geochemical and isotopic data. Geophysical information (gravimetric, seismic, aeromagnetic, aerogammaspectrometric, magnetotelluric) was integrated with our own data, leading to a model of an active continental margin, which was established and evolved during the late Neoproterozoic adjacent and to the south of the Patos continental boundary transform.

The convergent plate interaction proposed here is recorded along a ca. $750 \mathrm{~km}$ long belt, from the coastal area of Jacaraú, Paraíba ( $\left.\sim 6^{\circ} 40^{\prime} \mathrm{S}, 35^{\circ} \mathrm{W}\right)$ — northwest of João Pessoa, beneath Mesozoic sedimentary deposits —, to the Pernambuco-Piauí border $\left(-8^{\circ} S, 42^{\circ} \mathrm{W}\right)$ - south of Picos, Piauí, where it is covered by the Parnaíba Basin Paleozoic formations (Fig. 2). In the coastal Paraíba state (along meridian $45^{\circ} \mathrm{W}$ ), the northeastern largest portion of this accretionary orogenic zone is only ca. $20 \mathrm{~km}$ wide, reaching up to $140 \mathrm{~km}$ southwestward, close to longitude $39^{\circ} \mathrm{W}$. Evidence of the continuation of this accretionary belt in Africa has been recognized south of the Garoua lineament in Cameroon (Van Schmus et al. 2008, De Wit et al. 2008). Therefore, the original linear accretionary zone may have been thousands of kilometers long, bearing important implications for West Gondwana formation.

\section{PREVIOUS STUDIES}

The first references to the numerous granite intrusions in northeast Brazil, including reports on examples from the Transversal Zone, are from pioneering geologists such as D. Guimarães, L. J. Moraes, W. Kegel, among others, in informal reports at the beginning of the last century. More detailed studies of granites and related rocks in Borborema Province, particularly in the Transversal Zone, were triggered by the work of Almeida et al. (1967), during an international symposium sponsored by United Nations Educational, Scientific and Cultural OrganizationSuperintendência do Desenvolvimento do Nordeste (UNESCO-SUDENE), which included a field trip to the region. This outstanding work discriminated the main granite types - Conceição, Itaporanga, Catingueira, Itapetim - exposed in Borborema Province, including genetic inferences and time relations, in spite of the limited knowledge available at the time. The original concepts surrounding these granites were gradually improved by petrologic, geochemical and isotopic data in the following decades (Santos \& Brito Neves 1984, Santos et al. 1984,
Sial \& Ferreira 1985, Sial 1986, 1987), with many researchers emulating Almeida et al. (1967) after that.

An important development in the study of the granites in Brazil came about with the Núcleo de Estudos de Granitos (NEG), of the Universidade Federal de Pernambuco (UFPE), in 1984, followed by the Laboratório de Estudos Isotópicos (LABISE) in 1990 at the same university (Sial 1986, 1987, 1993, Ferreira \& Sial 1993, Mariano \& Sial 1993). Since then, NEG-LABISE has been conducting frontier research on the subject, sponsoring a number of theses and dissertations, scientific meetings and field trips, and publishing key scientific papers and reviews.

In the 1980s, a wider range of work became available due to larger scale geologic maps (Companhia de Pesquisa de Recursos Minerais-Departamento Nacional de Produção Mineral — CPRM-DNPM), as well as the publication of research papers (Sial 1986, 1987) and reviews (Santos \& Brito Neves 1984, Santos et al. 1984, Sial \& Ferreira 1985). The first International Symposium on Granites and Associated Mineralizations (ISGAM), in Salvador, took place in 1987, and many new scientific contributions were added to the knowledge of the granites exposed in the Transversal Zone, including a memorable field trip to their main exposures (Sial 1987).

From the 1990s on, several Master of Science (M.Sc.) dissertations and Doctor of Science (D.Sc.) theses (a large part from NEG-LABISE, UFPE) focused on specific granite intrusions, leading to knowledge improvement of these rocks. At the MAGMA workshop, sponsored by the Academia Brasileira de Ciências in 1993, several papers on granite magmatism were presented (Sial 1993, Ferreira \& Sial 1993, Mariano \& Sial 1993). Later on, several new contributions were presented during the II ISGAM (1997, Salvador), and another field trip was led to the Transversal Zone (Sial et al. 1997). This was followed by the review of Santos \& Medeiros (1999), proposing a system of granite suites and supersuites for the Transversal Zone (Figs. 1 and 2, Tab. 1).

At the beginning of the 21st century, geologic and petrologic knowledge of these granites were rather well established, thanks to continued investigation (Ferreira et al. 2004). Age determinations (TIMS/ U-Pb zircon, Brito Neves et al. 2003) constrained the main time intervals of the granite intrusions (namely 650-620 Ma, 590-570 Ma, and 545-520 Ma), grouped according to their main petrographic features and tectonic setting. Studies on the tectonics of the Transversal Zone led to the proposal of two distinct litho-structural domains (Brito Neves et al. 2005): the granite intrusions resulting from south-directed subduction are exposed to the north, whilst an arc of alkaline, and shoshonitic granites is observed to the south (syenitoid line of Sial 1993). The latter intrusions make up the so-called Teixeira-Terra Nova 
Tectonic Zone and display distinct petrologic and isotopic features, in particular Paleoproterozoic Rb-Sr ages and Sm/ $\mathrm{Nd} \mathrm{T}_{\mathrm{DM}}$ values (Brito Neves et al. 2005; recently reiterated by Archanjo et al. 2015).

Following subsequent reviews of the Borborema Province geology, encompassing the Transversal Zone granites (Delgado 2003, Ferreira et al. 2004), some new information became available (Sial et al. 2008, Ferreira 2010, Ferreira et al. 2014), including petrologic, geochemical, and isotopic evidences of south-directed subduction and the discrimination of possible remnants of ocean crust recorded as xenoliths in tonalite and granodiorite plutons of the Conceição type (Ferreira 2010, Ferreira et al. 2014). Sial and Ferreira (2015) published a recent and comprehensive synthesis about magma associations in the Transversal Zone.

\section{MAIN GEOLOGICAL FEATURES}

The aim of this paper was to suggest that there is a preserved Early Ediacaran (635-580 Ma) magmatic arc at the northernmost part of the Transversal Zone.

The proposed arc is exposed between $35^{\circ}-42^{\circ} \mathrm{W}$ (meridians) and 6040'8 S, ca. $750 \mathrm{~km}$ long, up to $140 \mathrm{~km}$ wide, southward the Patos Lineament. It extends from de coastal area to the east — "Zona da Mata", northeast of Paraíba state —, up to the Pernambuco-Piauí border — "Alto Sertão" - to the west, following a general ENE/WSW trend, more or less diagonally across the Transversal Zone.

Based on geological field observations, as well as on petrographic, petrological, geochemical and isotopic data compiled from many sources, about 90 different stocks and batholiths of I-type granitoids ("I" cordilleran, Pitcher 1983; "CAG", Maniar and Piccoli 1989; Hca, Barbarin 1990; Chappell and White 2001) were recognized and mapped along the northern part of the Transversal Zone (Tab. 2).
These rocks intruded preferentially into CryogenianEdiacaran low to medium grade schists of the Piancó-Alto Brígida (SPAB) system of orogens, and its basement, comprising older Neoproterozoic supracrustal belts - Cariris Velhos orogen, including the Alto Pajeú (TAP) and Riacho Gravatá (RG) terranes - and pre-Mesoproterozoic basement inliers, mostly Rhyacian and Orosirian in age (Figs. 1, 2 and 3). See syntheses and proposed maps of Santos et al. (2010) and Van Schmus et al. (2011).

\section{THE PLUTONIC SUPERSUITES}

\section{Classical supersuites}

Three supersuites of granitic rocks have long been recognized along the northern part of the Transversal Zone (Tab. 1). Most rock types are metaluminous to peraluminous (Ferreira et al. 2004), while a fourth type of peralkaline and ultrapotassic rocks is metaluminous. Magmatic epidote-bearing calc-alkaline, in part high-K calc-alkaline, granitoids (Conceição-type), form the most common stocks and batholiths in the northern part of the Transversal Zone. They are usually metaluminous to slightly peraluminous, equigranular, medium to coarsegrained tonalite and granodiorite intrusions (Tab. 2, Figs. 2, 4 and 5). The plutons have a rather constant composition (quartz + feldspars + Ca-amphibole + biotite + epidote + apatite, Ferreira et al. 2004), generally following the trends of I-type granitoids, according to the Chappell and White (2001) classification.

A very typical feature is the presence of amphibole-rich cloths, which can be observed in rocks from the northern coastal area of Paraíba to the far west of Pernambuco. Some of these amphibolitic portions, especially in the Curral de Cima, Emas and Tavares batholiths (Sial 1993, Ferreira 2010), support the hypothesis that they are altered seafloor basalts trapped as xenoliths. Rounded, elongated

Table 1. Main supersuites and suites of igneous rocks of the Transversal Zone, central subprovince of the Neoproterozoic Borborema Structural Province (Santos \& Medeiros 1999).

\begin{tabular}{l|c|c|c}
\hline Orogeny & Supersuites & Suites & Examples \\
\hline \multirow{2}{*}{ NEOPROTEROZOIC } & \multirow{3}{*}{ Calc-alkalic } & High-K calc-alkalic & Itaporanga, Lagoinha \\
\hline \multirow{2}{*}{ (Cryogenian-Ediacaran) } & & Calc-alkalic & Conceição, Emas \\
\hline \multirow{2}{*}{ Brasiliano Cycle } & & Trondhjemitic affinities & Serrita, Salgueiro \\
\cline { 3 - 4 } & & Peralkalic silica-oversaturated & Catingueira, Moderna \\
\hline \multirow{2}{*}{ Ultrapotassic/ Shoshonitic } & Peralkalic silica-saturated & Triunfo, Terra Nova \\
\cline { 3 - 4 } & & Shoshonitic & Teixeira, Toritama \\
\cline { 3 - 4 } & & Post-orogenic/A-type & \\
\hline
\end{tabular}


Table 2. Examples of the main granitic plutons of the Transversal Zone with their main characteristics, according to available academic theses, dissertations and other published papers.

\begin{tabular}{|c|c|c|c|c|c|c|}
\hline Locality name & Petrography & $\begin{array}{l}\text { Remarkable } \\
\text { minerals and } \\
\text { features }\end{array}$ & $\begin{array}{l}\text { Autoliths/ } \\
\text { xenoliths }\end{array}$ & $\begin{array}{l}\text { Geochemical } \\
\text { features }\end{array}$ & $\begin{array}{l}\text { U-Pb } \\
\text { Age } \\
\mathrm{Ma}\end{array}$ & $\begin{array}{c}\text { Main } \\
\text { references }\end{array}$ \\
\hline $\begin{array}{l}\text { CURRAL CIMA/ } \\
\text { JACARAÚ-PB } \\
\text { 35o/3515' - } \\
\text { 06²0' } \\
\text { Fig. 5A }\end{array}$ & $\begin{array}{c}\text { Tonalites, quartz } \\
\text { diorites } \\
\text { (Epid.-bearing CA) }\end{array}$ & $\begin{array}{l}\text { Magmatic } \\
\text { epidote }\end{array}$ & $\begin{array}{l}\text { Amphibole-rich } \\
\text { cloths } \\
\text { Remnants of } \\
\text { oceanic crust }\end{array}$ & $\begin{array}{c}\text { I-type (VAG) + S- } \\
\text { type } \\
\text { Peraluminous } \\
\text { Low }{ }^{\varepsilon} \mathrm{Nd} \text { values }\end{array}$ & $618 \pm 10$ & $\begin{array}{l}\text { Ferreira et al. } \\
\quad(2014) \\
\text { Brito Neves } \\
\text { et al. } \\
(2008)\end{array}$ \\
\hline $\begin{array}{l}\text { CAMPINA } \\
\text { GRANDE } \\
\text { SERRA } \\
\text { REDONDA-PB } \\
\text { 35036'/35054' - } \\
\text { 7o15' }\end{array}$ & $\begin{array}{l}\text { Composition ranging } \\
\text { from monzodiorite, } \\
\text { granodiorite to } \\
\text { quartz monzonite } \\
\text { + mafic facies of } \\
\text { K-dioritic nature } \\
\text { (Epid.-bearing HKCA) }\end{array}$ & $\begin{array}{l}\text { Enclaves within } \\
\text { felsic rocks, } \\
\text { products of } \\
\text { mingling between } \\
\text { coeval granitic and } \\
\text { dioritic magmas. } \\
\text { Mafic rocks with } \\
\text { augite }\end{array}$ & & $\begin{array}{c}\text { High-K calc- } \\
\text { alkaline chemistry } \\
\text { VAG } \\
\text { Metaluminous }\end{array}$ & $581 \pm 1.6$ & $\begin{array}{l}\text { Almeida et al. } \\
\qquad(2002)\end{array}$ \\
\hline $\begin{array}{l}\text { EMAS-PB } \\
37^{\circ} 45^{\prime}-7^{\circ} 10^{\prime} \\
\text { Figs. 5B and 5C }\end{array}$ & $\begin{array}{c}\text { Fine-grained } \\
\text { (equigranular) } \\
\text { and porphyritic } \\
\text { granodiorites } \\
\text { (Epid.-bearing CA) }\end{array}$ & $\begin{array}{l}\text { Magmatic epidote, } \\
\text { zoned plagioclase }\end{array}$ & $\begin{array}{l}\text { Amphibolites } \\
\text { (with biotite and } \\
\text { hornblende) } \\
\text { Remnants of } \\
\text { oceanic crust }\end{array}$ & $\begin{array}{l}\text { I-type (VAG) } \\
\text { Metaluminous }\end{array}$ & - & Goist (1989) \\
\hline $\begin{array}{l}\text { BREJINHO-PE } \\
37015^{\prime}-7022^{\prime} \\
\text { Figs. 5D and 5E }\end{array}$ & $\begin{array}{c}\text { Porphyritic } \\
\text { monzogranitic/ } \\
\text { granodioritic rocks } \\
\text { + quartz diorites } \\
\text { (mostly as enclaves) } \\
\text { (Epid.-bearing HKCA) }\end{array}$ & $\begin{array}{c}\text { Magmatic epidote, } \\
\text { titanite }\end{array}$ & $\begin{array}{l}\text { Quartz diorites, } \\
\text { diorites enclaves } \\
\text { and dikes (see } \\
\text { photo) }\end{array}$ & $\begin{array}{l}\text { I-type }+(\mathrm{VAG}), \\
\text { High-K calc- } \\
\text { alkaline, } \\
\text { metaluminous } \\
\text { Low }{ }^{\varepsilon} \mathrm{Nd} \text { values }\end{array}$ & $638 \pm 15$ & Torres (2001) \\
\hline $\begin{array}{l}\text { CONCEIÇÃO-PB } \\
38^{\circ} 30^{\prime}-07^{\circ} 34^{\prime} \\
\text { Figs. 5F and } 5 G\end{array}$ & $\begin{array}{l}\text { K-diorites, tonalites, } \\
\text { hornblende-biotite } \\
\text { granodiorites } \\
\text { (Epid.-bearing CA) }\end{array}$ & $\begin{array}{l}\text { Hornblende, biotite, } \\
\text { magmatic epidote }\end{array}$ & $\begin{array}{l}\text { Quartz diorites, } \\
\text { amphibolites }\end{array}$ & $\begin{array}{l}\text { I-type (VAG) } \\
\text { High-K calc- } \\
\text { alkalic. } \\
\text { Meta- to } \\
\text { peraluminous }\end{array}$ & $635 \pm 9$ & $\begin{array}{l}\text { Cunha (1994) } \\
\text { Barriga (1983) }\end{array}$ \\
\hline $\begin{array}{l}\text { TAVARES-PB } \\
\text { 37o54' - 7o36' } \\
\text { Figs. 5H and 5I }\end{array}$ & $\begin{array}{c}\text { Syeno-granites, } \\
\text { quartz } \\
\text { syenites, } \\
\text { monzogranites and } \\
\text { quartz monzonites } \\
\text { Epid.-bearing HKCA }\end{array}$ & $\begin{array}{c}\text { Magmatic } \\
\text { epidote } \\
\text { Syn-plutonic dykes } \\
\text { Ladder dikes and } \\
\text { snail structures }\end{array}$ & $\begin{array}{l}\text { Syn-plutonic } \\
\text { dikes and } \\
\text { magmatic enclaves } \\
\text { of K- diorites } \\
\text { Amphibolitic, } \\
\text { remnants of } \\
\text { oceanic crust }\end{array}$ & $\begin{array}{c}\text { I-type (VAG) } \\
\text { High K calc-alkalic, } \\
\text { metaluminous }\end{array}$ & $651 \pm 15$ & $\begin{array}{l}\text { Pessoa (2001) } \\
\text { Brito Neves } \\
\text { et al. (2008) } \\
\text { Ferreira et al. } \\
\quad(2014)\end{array}$ \\
\hline $\begin{array}{l}\text { ITAPORANGA } \\
\text {-PB } \\
38^{\circ} 09^{\prime}-7^{\circ} 16^{\prime} \\
\text { Figs. 6A-6C }\end{array}$ & $\begin{array}{l}\text { Compositional } \\
\text { gradation from } \\
\text { K- diorite, } \\
\text { monzodiorite, } \\
\text { quartz monzonite, } \\
\text { granodiorite to } \\
\text { granite (interaction } \\
\text { of K- diorites and } \\
\text { granitic } \\
\text { magmas) } \\
\text { (Epid.-free HKCA) }\end{array}$ & $\begin{array}{l}\text { Hornblende and } \\
\text { biotite. Usually } \\
\text { porphyritic rocks } \\
\text { K-feldspars up to } \\
\text { 10cm } \\
\text { (“migmatitic” } \\
\text { features are } \\
\text { common) }\end{array}$ & $\begin{array}{l}\text { (High-K) quartz } \\
\text { diorites, with } \\
\text { mingling and } \\
\text { mixing features } \\
\text { Evidences of } \\
\text { successive mafic } \\
\text { magma supplies }\end{array}$ & $\begin{array}{l}\text { High-K calc- } \\
\text { alkaline } \\
\text { (epidote free) } \\
\text { granitoids } \\
\text { Mostly VAG types } \\
(\rightarrow \text { WPG })\end{array}$ & $584 \pm 2$ & $\begin{array}{c}\text { Mariano (1989) } \\
\text { Mariano et al. } \\
\text { (1990) } \\
\text { Mariano \& Sial } \\
\text { (1990) } \\
\text { Ferreira et al. } \\
\text { (2004) }\end{array}$ \\
\hline $\begin{array}{l}\text { SERRA DA } \\
\text { LAGOINHA-PB } \\
\text { 38०35' - 7०30' }\end{array}$ & $\begin{array}{c}\text { Porphyritic } \\
\text { biotite- granites > } \\
\text { hornblende-biotite } \\
\text { granite } \\
\text { Epid.-free HKCA }\end{array}$ & $\begin{array}{c}\text { Titanite, opaque } \\
\text { minerals } \\
\text { Perthites up to 5- } \\
\text { cm long (“flame” > } \\
\text { "patch”) K-dioritic } \\
\text { enclaves, sharp } \\
\text { contacts } \\
\text { Occasional mafic } \\
\text { xenoliths }\end{array}$ & $\begin{array}{c}\text { K-dioritic enclaves, } \\
\text { sharp contacts } \\
\text { Occasional mafic } \\
\text { xenoliths }\end{array}$ & $\begin{array}{l}\text { High-K calc- } \\
\text { alkaline } \\
\mathrm{Na2O}, \mathrm{K} 2 \mathrm{O} \text { and } \\
\text { TiO2-rich rocks }\end{array}$ & & Barriga (1983) \\
\hline
\end{tabular}


Table 2. Continuation.

\begin{tabular}{|c|c|c|c|c|c|c|}
\hline Locality name & Petrography & $\begin{array}{c}\text { Remarkable } \\
\text { minerals and } \\
\text { features }\end{array}$ & $\begin{array}{l}\text { Autoliths/ } \\
\text { xenoliths }\end{array}$ & $\begin{array}{l}\text { Geochemical } \\
\text { features }\end{array}$ & $\begin{array}{l}\text { U-Pb } \\
\text { Age } \\
\mathrm{Ma}\end{array}$ & $\begin{array}{c}\text { Main } \\
\text { references }\end{array}$ \\
\hline $\begin{array}{l}\text { EXU-BODOCÓ- } \\
\text { PE } \\
\text { 39o30'/40o - } \\
\text { 7030' }\end{array}$ & $\begin{array}{l}\text { Porphyritic coarse- } \\
\text { grained quartz } \\
\text { monzonite, quartz } \\
\text { monzodiorite } \\
\text { (little variation in } \\
\text { composition) } \\
\text { "plumose" and } \\
\text { "porphyritic" } \\
\text { Epid.-free HKCA }\end{array}$ & $\begin{array}{l}\text { Perthitic K- feldspar } \\
\text { up to 5- cm long. } \\
\text { Calcic- amphiboles, } \\
\text { allanite, } \\
\text { clinopyroxene }\end{array}$ & $\begin{array}{c}\text { Many mafic } \\
\text { enclaves. Some } \\
\text { microgranitoid } \\
\text { enclaves } \\
\text { Mafic dikes with } \\
\text { sharp contacts }\end{array}$ & $\begin{array}{l}\text { High-K calc- } \\
\text { alkaline ( } \\
\text { Itaporanga) }\end{array}$ & $\begin{array}{c}590- \\
560^{*}(\mathrm{Rb} \\
\quad-\mathrm{Sr})\end{array}$ & $\begin{array}{l}\text { McMurry } \\
(2001) \\
\text { McMurry } \\
(1995)\end{array}$ \\
\hline $\begin{array}{l}\text { SERRITA-PE } \\
\text { 39०-16' - } \\
7^{\circ}-54^{\prime} / 8^{\circ}-00^{\prime}\end{array}$ & $\begin{array}{l}\text { Epidote-bearing and } \\
\text { biotite granodiorites } \\
\text { predominate in the } \\
\text { cores of the stocks } \\
\text { + rims of aegirine- } \\
\text { granites } \\
\text { (Epid.-bearing CA) }\end{array}$ & $\begin{array}{l}\text { Rims of aegirine } \\
\text { granite are in } \\
\text { topographic relief. } \\
\text { Xenoliths of the } \\
\text { enclosing rocks are } \\
\text { rare }\end{array}$ & $\begin{array}{l}\text { Characteristic } \\
\text { circular shapes } \\
\text { Near the intrusive } \\
\text { contacts, granitic } \\
\text { sills following the } \\
\text { schistosity of the } \\
\text { enclosing rocks }\end{array}$ & $\begin{array}{c}\text { Biotite } \\
\text { granodiorites } \\
\text { exhibit } \\
\text { trondhjemitic } \\
\text { affinities } \\
\text { and meta- to } \\
\text { peraluminous } \\
\text { character } \\
\text { Aegirine-granites } \\
\text { show peralkaline } \\
\text { tendency }\end{array}$ & - & Neves (1986) \\
\hline $\begin{array}{l}\text { FELSIC DIKES } \\
\text { AND SILLS } \\
\text { Figs. } 7 \mathrm{~A}-7 \mathrm{C}\end{array}$ & $\begin{array}{c}\text { Rhyolites, } \\
\text { rhyodacites and } \\
\text { dacites }\end{array}$ & $\begin{array}{l}0.5 \text { to } 2.0-\mathrm{m} \text { thick, } \\
\text { concordant to } \\
\text { sub-concordant } \\
\text { with the enclosing } \\
\text { schists }\end{array}$ & & $\begin{array}{l}\text { VAG, with } \\
\text { trondhjemitic } \\
\text { affinities }\end{array}$ & $650-630$ & Brito (2014) \\
\hline
\end{tabular}

HKCA: high K calc-alkalic magma association; CA: calc-alkalic magma association; Epid.-bearing CA: calc-alkalic magma association with epidote; VAG: volcanic arc granite; WPG: within plate granites. (Sial \& Ferreira 2015)

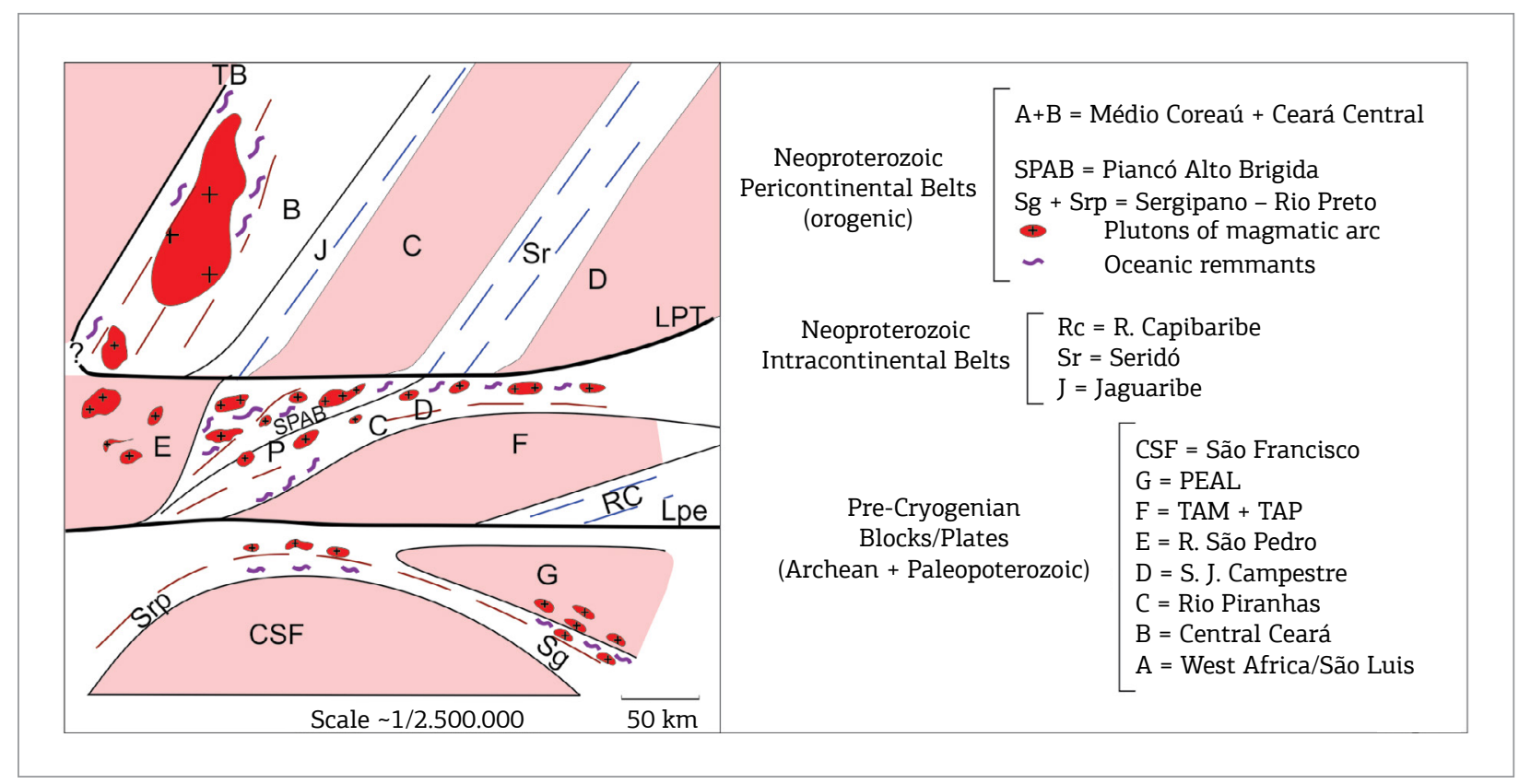

Figure 3. Tectonic sketch of the Borborema Province, trying to highlight the main known Neoproterozoic (Cryogenian-Ediacaran) accretionary orogenic developments: (A) the NNE-SSW trending Tamboril-Santa Quitéria, west of Ceará state; (B) north of the E-NE/W-SW trending Transversal Zone, object of this paper; (C) parallel to (and following) the northern margin of the São Francisco Craton. A probable former connection between (A) and (B) is suggested in this sketch. 
quartz diorite enclaves are ubiquitous, sometimes displaying a breccia-like pattern. In tectonic discrimination diagrams (e.g., Pearce et al. 1984), the epidote-bearing granites show a very clear position in the volcanic arc granites (VAG) field of arc granitoids. This is also true for the rhyodacite and dacite dikes of trondhjemitic affinity that cut through the Salgueiro Group supracrustals in many outcrops (Brito 2014).

Isotopic data for these granodiorites and tonalites are still scarce. Generally, the $\mathrm{T}_{\mathrm{DM}}$ values vary from 1.3 to $1.8 \mathrm{Ga}$, and the $\mathrm{Nd}$ values vary from positive (one or two cases) to negative (from +2 to -10 ). Most of the $\mathrm{U}-\mathrm{Pb}$ isotopic determinations indicate Early Ediacaran ages (Tab. 2, Figs. 4, 5A-5I).

The Itaporanga-type plutons are heterogeneous in composition, and broadly correspond to a high-K calc-alkaline series (Mariano 1989, Mariano et al. 1990). They encompass compound batholiths, formed by dominant porphyritic granite (microcline-rich granite) to quartz monzonite types. These rocks are, in many places, accompanied by early- to syn-plutonic, dominantly K-rich diorites, and by an intermediate equigranular granite association (Mariano \& Sial 1993, Santos \& Medeiros 1999). The most usual feature, taken as basis for their recognition, is the porphyritic texture, characterized by large — up to 10-cm-long — K-feldspar megacrysts. The porphyritic assemblages display features of magma mixing with dioritic portions. These apparent migmatitic features, rendered by magmas of contrasting compositions, are rather common, and thought to be the product of successive pulses of mafic magma supply, indicating coexistence and mixing of felsic and mafic magmas (Mariano \& Sial 1993). Migmatite-like, stromatic and agmatic structures are common, as well as pillow-like and irregular-shaped mafic enclaves. The Itaporanga-type granite was defined in the northern part of the Transversal Zone (Almeida et al. 1967), but has unfortunately been mistakenly applied to granites that outcrop in other tectonic domains of Borborema Province, based on apparently similar general features (Figs. 6A-6C).

Isotopic data for the Itaporanga-type granites are rather scarce. Generally, $\mathrm{T}_{\mathrm{DM}}$ model ages are between 1.6 and $2.5 \mathrm{Ga}$, and the $\mathrm{Nd}$ values are usually negative, from -8.0 to $-16,5$. Some of these granite intrusions crosscut the basement inliers of the low-grade schists belts (Sistema de Dobramentos Piancó-Alto Brígida - SPAB), and present strongly negative $\mathrm{Nd}$ values. For the typical locality, there is a previous $\mathrm{U} / \mathrm{Pb}$ age of $584 \pm 2 \mathrm{Ma}$ (TIMS, Brito Neves et al. 2003).

At least three granitic stocks within the tectonic domain of the Transversal Zone are part of the trondhjemitic suite. They are epidote-bearing biotite granodiorites, surrounded by aegirine granite rims. Rocks form the central parts of the intrusions plot within or next to the trondhjemitic field, whereas rim samples plot in the granite field in Barker's Ab-An-Or diagram. The biotite granodiorites are meta- to peraluminous, whereas the aegerine granites show a peralkaline
A

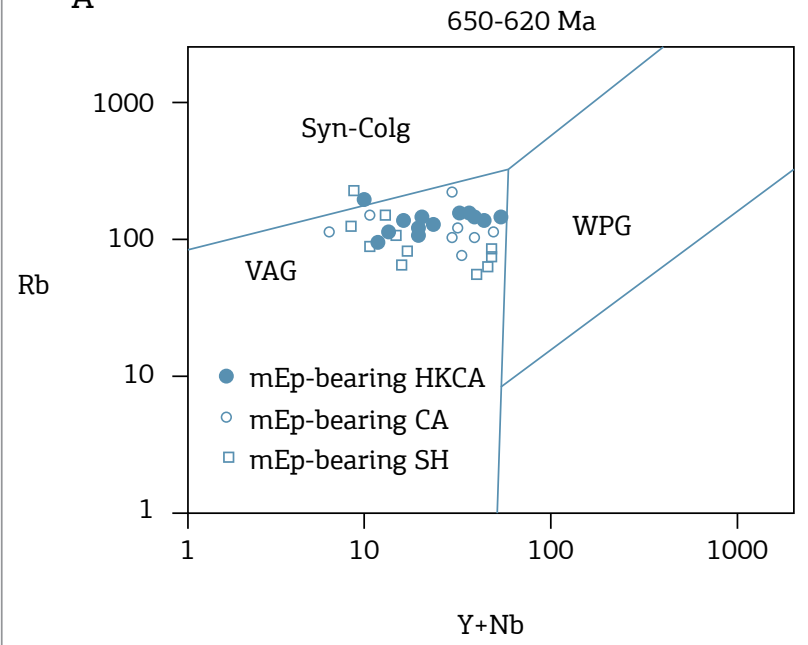

$\mathrm{B}$

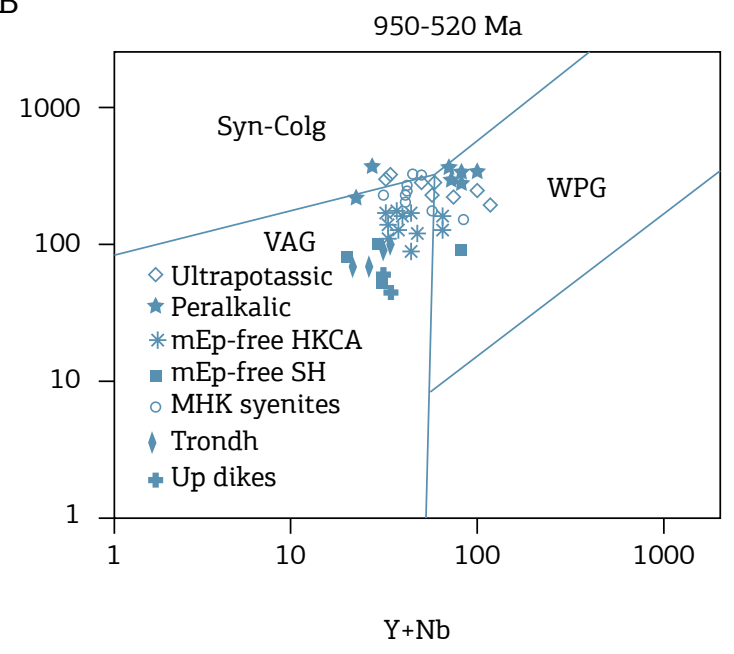

Figure 4. Granitoids and syenitoids of the Transversal Zone represented in Pearce et al. (1984) tectonic discriminant diagram (log Rb vs. $\log \mathrm{Y}+\mathrm{Nb}$ ). Adapted from Ferreira et al. (2004). (A) 650-620 Ma group: mEp-bearing HKCA: magmatic epidote-bearing high-K calc alkalic; mEp-bearing CA: magmatic epidote bearing calc alkalic; mEpbearing SH: magmatic epidote-bearing shoshonitic; (B) 590-540 Ma group: trondh.: trondhjemitic (mostly plotting in the VAG field); mEp-free HKCA: magmatic epidote-free high-K calc alkalic; MHK syenites: mafic high-K syenites; Ultrapotassic rocks; Up: ultrapotassic dikes; peralkalic dikes. 
trend (Neves 1986). Generation through garnet amphibolite partial melting is compatible with the geochemical data recently obtained for the granodiorites. The contacts with the enclosing low-grade schists of the CachoeirinhaSalgueiro Group are usually sharp. The granitic stocks may partially intrude the Paleoproterozoic basement inlier in the so-called Icaiçara terrane, located in west Pernambuco (Santos et al. 2010). There are some still unpublished U-Pb ages (verbal information, from Sial, A.N.), pointing out similar ages to that of Conceição type (ca. $630 \mathrm{Ma}$ ).
The peralkalic, silica saturated and shoshonitic plutons and dikes were emplaced along a straight contour line at the southern limit of the inferred main part of the magmatic arc, comprising the three groups of intrusions described before.

This special group of intrusions was described as the syenitoid line (Sial 1986) or as Teixeira-Terra Nova tectonic zone (Brito Neves et al. 2005), designations that may now be considered as obsolete. The plutons vary from syenogranites to syenites in composition. The peralkaline types include aegerine-augite and/or richterite as the main mafic silicates
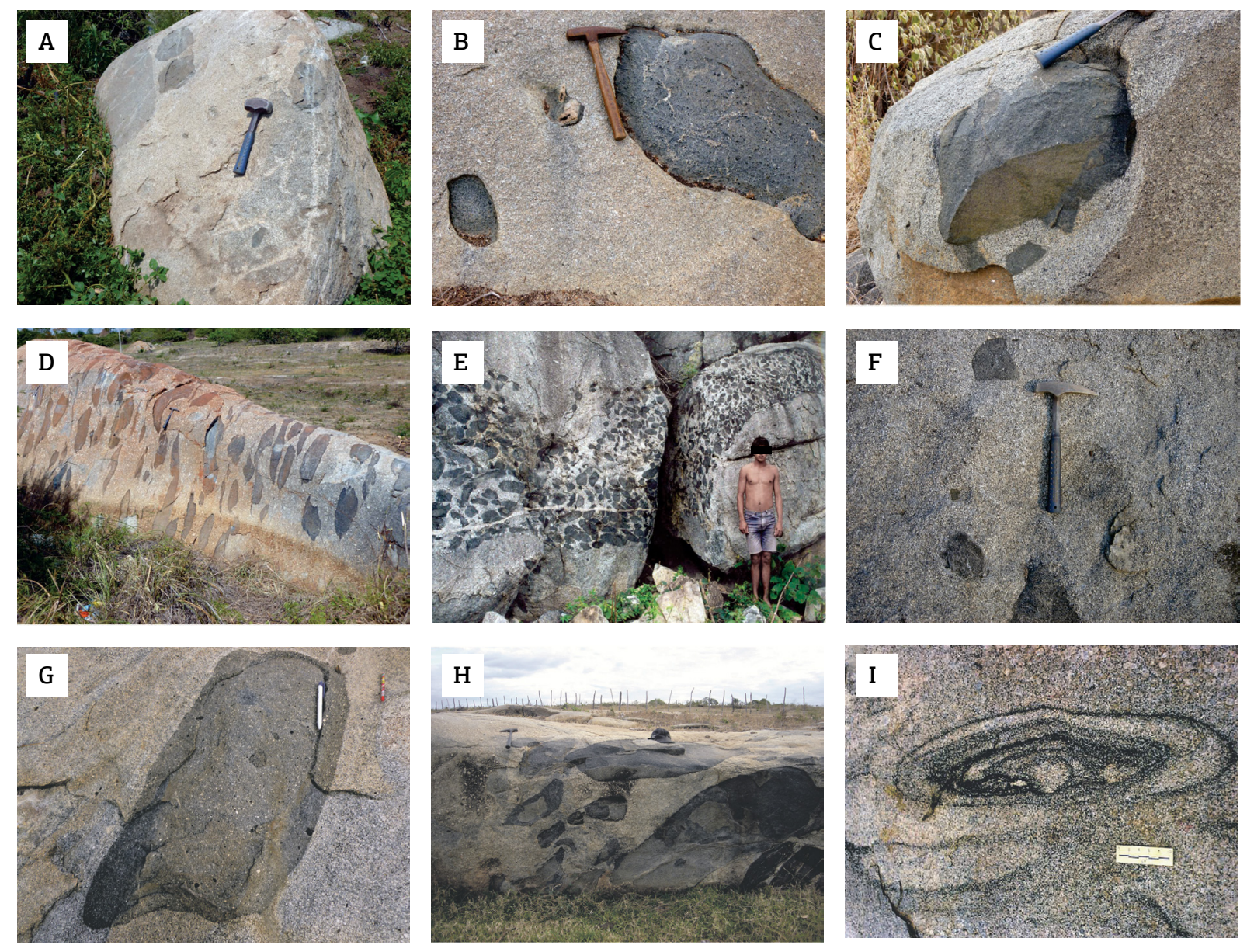

Figure 5. Photos of the main Conceição-type granodiorites and tonalites. (A) Curral de Cima granodiorite with different mafic enclaves, at the easternmost part of the accretionary development. Locally, low- $\mathrm{K}$ metabasalts taken as probable remnants of oceanic crust occur (Brito Neves et al. 2008, Sial \& Ferreira 2015); (B) Emas Batholith exhibiting mafic/dioritic enclaves of K-dioritic composition containing amphibole-rich cloths. Some of the enclaves present characteristics of low-K metabasalts. Near Emas township; (C) K-dioritic enclaves surrounded by a coarse-grained granodioritic matrix. Between Emas and Olhos d'Água (Goist 1989; Tab. 2); (D) magma mixing in the Brejinho pluton, presenting E-W flow strike with subvertical dip. Nicknamed "leopard skin", it occurs in the Brejinho township; (E) Channel of pillow-like K-diorite in a more granodioritic matrix, $29 \mathrm{~km}$ SW of Brejinho (Torres 2001; Tab. 2); (F) Conceição granodiorite presenting small polygonal and sub-rounded K-dioritic enclaves, without structural orientation. Conceição township, typical locality; (G) large K-dioritic enclaves exhibiting centimeter-sized fragments and amphibole-rich cloths. Between Conceição and Ibiara (Barriga 1983, Cunha 1994; Tab. 2); (H) Tavares pluton of syenogranitic to monzogranitic composition with a great amount of large mafic enclaves; (I) concentric magmatic (rhythmic) structure with an elliptical section. Felsic and mafic bands (biotite rich) alternating almost regularly. The core is formed of K-feldspar megacrystals (photo from Pessoa, 2001). 
(Archanjo et al. 2015). The dikes are peralkaline to ultrapotassic. This last group of intrusions appears to constitute the most distal part of the magmatic arc, representing the
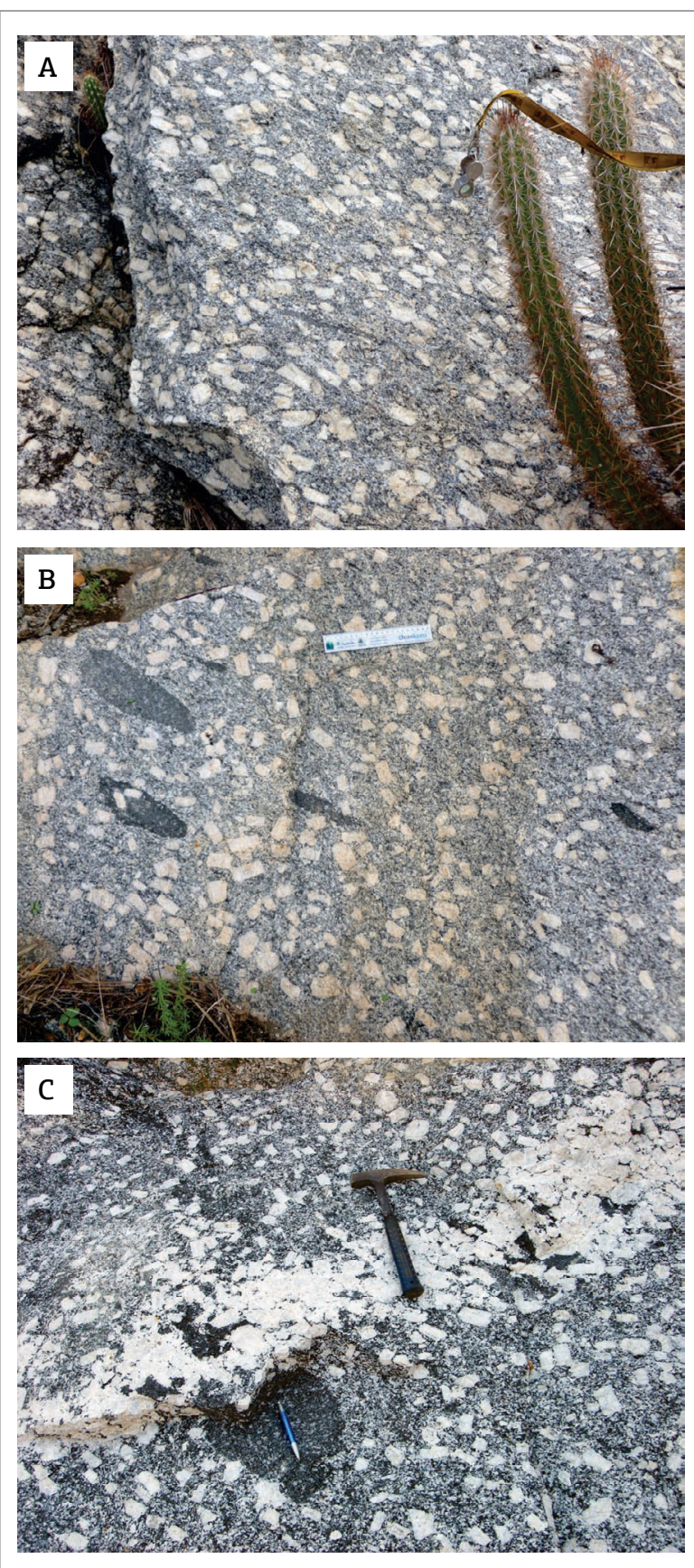

Figure 6. Photos of the Itaporanga-type granites. (A) Local concentration of K-feldspar crystals and mafic enclaves (K-dioritic composition). The general flow orientation is locally not preserved; (B) K-diorite enclaves in the Itaporanga granite (main quarry, near Itaporanga township) and typical porphyritic granite, both following the igneous flow (Mariano 1989, Mariano et al. 1990); (C) porphyritic (K-feldspar) granites predominate. Composition grading from $\mathrm{K}$-diorite to granite. Weak flow orientation of K-feldspar crystals. farthest intrusions from the subduction zone. Alternatively, they may represent magmatic activity recording the transition of tectonic regimes, from a compressive, convergent and collisional setting to a post-collisional one, associated with the first post-arc rupture. Still scarce U-Pb and Ar-Ar isotopic studies indicate ages between 600 and $590 \mathrm{Ma}$ (Archanjo et al. 2015).

In addition to the plutonic rocks, the study area is characterized by many swarms of $\mathrm{cm}$-m thick felsic dikes, generally concordant to sub-concordant with black (Salgueiro Group) and green (Cachoeirinha Group) schists, and in part with the rocks of the Early Tonian RG Complex (Figs. 1, 2 and 7A-7C). They comprise light-colored metarhyodacite, metadacite and meta-andesite, usually preserving their igneous texture. They are mostly acid, peraluminous, calc-alkaline rocks, classified as ferrous to magnesian, and calcic to alkaline (Brito 2014). Their geochemical signature points to subduction-related environments, independent from their Brasiliano or Cariris Velhos country rocks. The dike rocks are yet poorly studied, though it appears they are absent northward, in Rio Salgado Belt.

\section{THE MAGMATIC ARC PROPOSAL}

The geological and tectonic studies carried out in the study area led us to infer the presence of a magmatic arc, encompassing the main suites of plutonic rocks described before (Tabs. 1 and 2), namely the Conceição, Itaporanga, and Serrita types and rocks alike.

The continental part of the lower plate (to the north of the Patos Lineament) comprises the Central Ceará, OrósJaguaribe and Rio Grande do Norte domains, and is characterized by NNW-SSW trending Paleoproterozoic mobile belts, surrounding several Archean nuclei (Figs. 1 and 2). The former oceanic segment of this lower plate was completely recycled in the mantle by southward B-subduction in Late Cryogenian-Early Ediacaran times. Scarce remnants of the former oceanic rocks are observed among the low-grade SPAB Belt, or even as preserved xenoliths within the Conceição-type tonalite and granodiorite intrusions (Ferreira 2010, Sial \& Ferreira 2015). This is especially observed in the enclaves of the Curral de Cima, Emas and Tavares plutons (Tab. 2).

The Transversal Zone itself, south of the Patos Lineament, represents most of the former upper continental plate. It displays a very complex tectonic framework of Neoproterozoic fold belts, including the Tonian Cariris Velhos RG and TAP Belts, plus two Cryogenian-Ediacaran belts: SPAB and Rio Capibaribe (RC). Additionally, this central subprovince exhibits several Paleoproterozoic (pre-Statherian) basement 
inliers or terranes (Fig. 2). The Paleoproterozoic Alto Moxotó Terrane (TAM) — that includes some local Archean cores is the southernmost basement of the Transversal Zone, and
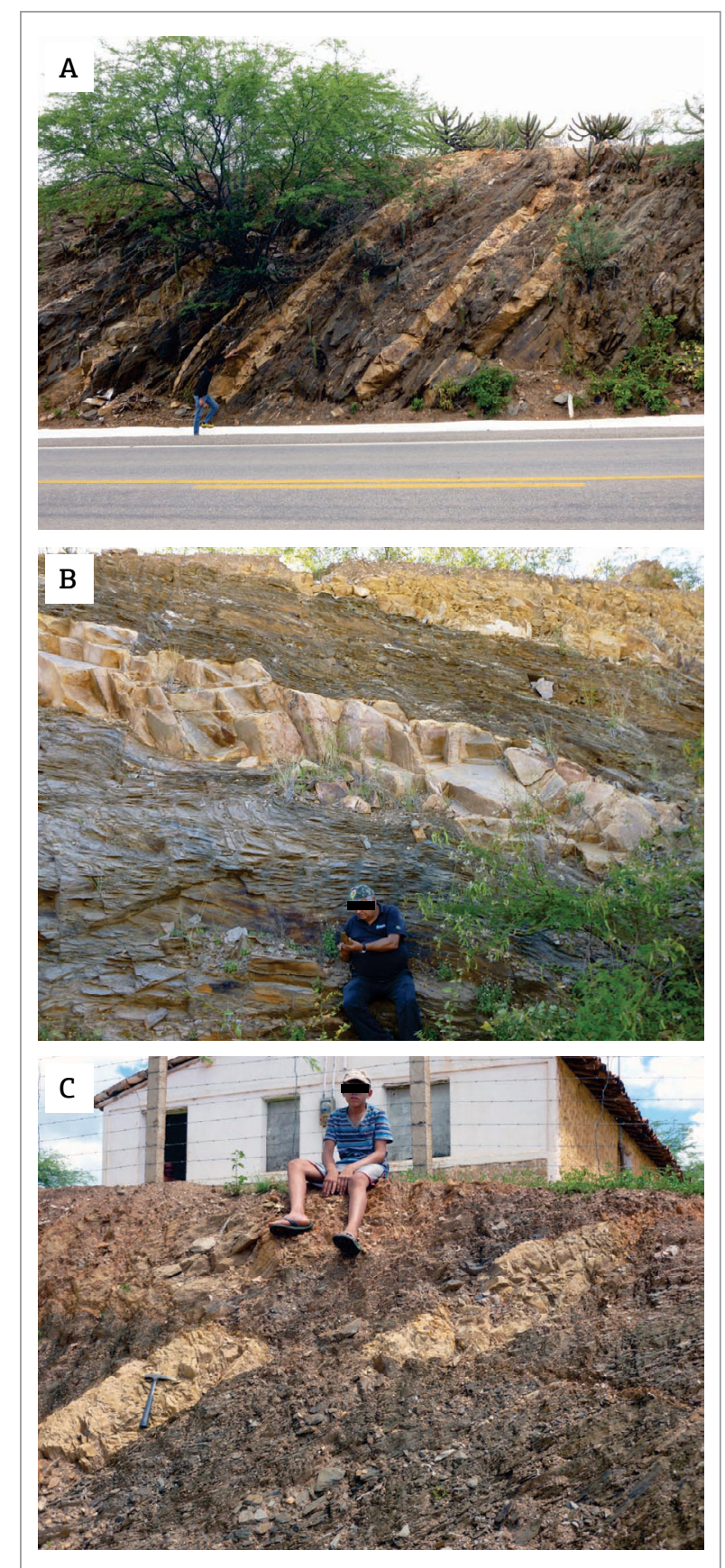

Figure 7. Photos of the felsic dykes. (A) Felsic subconcordant dikes intrusive in low-grade schists ("Salgueiro group"); $\mathrm{km} \mathrm{540,} \mathrm{BR-232,} \mathrm{west} \mathrm{of}$ Salgueiro, Pernambuco; (B) felsic dikes (rhyodacitic composition) along a road cut of the "Transnordestina railway", alternating with low-grade schists of the "Cachoeirinha Group"; north of Salgueiro, Pernambuco; (C) Stretched felsic dikes presenting "boudinage" near Curral Velho, Paraíba. Rhyolitic to rhyodacitic compositions (Brito 2014; Tab. 2). apparently behaved as a backland domain. At the northern edge of this upper plate, rock units of the Rio Salgado Belt (RS) (Brito Neves \& Campos Neto 2015) are preliminarily interpreted as the result of a former forearc basin.

The limit between these two inferred plates is presently marked by a boundary transform, the Patos Lineament plus the Malta Shear zone, an up to $20 \mathrm{~km}$ wide and $750 \mathrm{~km}$ long belt of tectonites, and the so-called Mataraca-Fronteiras keirogen, placed at the southern edge of the continental part of the lower plate (Brito Neves et al. 2015a). Many compositional, structural, and chronological differences exist between the northern segment (Fig. 1, Tab. 3), considered as the continental part of the lower plate, and the southern segment - the Transversal Zone - considered to have been the upper plate during the Cryogenian-Early Ediacaran subduction processes. Table 3 was organized so as to synthesize the main contrasting differences (compositional, structural, tectonic, chronological, etc.) between these two segments of proposed Neoproterozoic plates.

\section{Some geochemical and isotopic data}

The amount of available petrographic, petrological, and geochemical data, despite being rather good, is still insufficient to further develop our magmatic-tectonic model. The preliminary isotopic data are not sufficient to acknowledge all the controversies raised by the hypothesis proposed herein, of a Late Neoproterozoic magmatic arc developed in the northern part of the Transversal Zone. Nevertheless, the integrated data allow us to build a compatible model to the overall geological-tectonic scenario we deduce from field relations.

It is well known that it is not possible to associate a geotectonic context with the characteristics of the produced arc magmatism in a simplistic way (Nédeléc $\&$ Bouchez 2011). The formation of hybrid granitoids with mixed isotopic signatures is recorded in all the cases of plate interactions involving subduction, due to different kinds of sources and to their participation in different proportions in arc magma generation. Therefore, variation of granite types is a fact, as indicated by discriminant geochemical diagrams. Such diagrams (Fig. 4) should be drawn having in mind that they are just a tool, and not the final statement. These diagrams should be seen with the necessary precautions.

Regarding the granite types, subsequent to the contributions of Santos \& Medeiros (1999) (Tab. 1), Brito Neves et al. (2003) and Ferreira et al. (2004) (Fig. 4), this topic was recently enriched with the contribution by Ferreira et al. (2011) and Sial \& Ferreira (2015), as part of the celebration of the NEG-LABISE 40th anniversary. These authors have recognized the following group of magmatic associations for the Transversal Zone as a whole: 
Table 3. Comparison between the lithospheric domains (plates) separated by the Patos Lineament.

\section{Northern domain \\ (Lithospheric continental segment of the lower plate) \\ Ceará Central + Orós-Jaguaribe + RG do Norte}

Structural grain of older terranes and Brasiliano mobile belts: NNE-SSW

\section{Transversal zone domain \\ (Lithospheric continental segment of the upper plate) SPAB + RG + TAP + TAM ( TRC)}

Structural grain of Paleoproterozoic terranes and Tonian and Brasiliano mobile belts: from E-W to ENE-WSW

Paleoproterozoic (Rhyacian > Orosirian > Siderian) basement with local Neoarchean inliers

Paleoproterozoic basement with Paleo-, Meso- and Neoarchean nuclei

Presence of an important terrane - Granja terrane - (Médio

Coreaú domain, NW of the province) composed of TTG

orthogneisses and kinzigites of Siderian age

Presence of a belt composed of a Statherian volcanosedimentary sequence plus anorogenic granites deformed during Brasiliano events (Jaguaribeano Belt, Ceará state)

Rare Statherian anorthosite magmatism

\begin{tabular}{l|c}
\hline apparently missing & $\begin{array}{c}\text { Sparse Mesoproterozoic (Calymmian, Ectasian, Stenian) felsic } \\
\text { magmatism during local extensional events }\end{array}$
\end{tabular}

apparently missing

Late Stenian to Early Tonian accretionary and collisional processes (Cariris Velhos Orogeny: 1.050-930 Ma); rare anorogenic intrusions

Intracontinental Neoproterozoic mobile belts deforming Statherian and Cryogenian-Ediacaran volcano-sedimentary sequences at ca. 600-580 Ma, followed by magmatism from $560 \mathrm{Ma}$ onwards, including dikes and pegmatites

apparently missing

Important accretionary belt (NNE-SSW) in western Ceará (Santa Quitéria arc, >300 km long), including arc plutonism and retroeclogites, probable continuation of the (Pan-African) Pharusian belt in the South-American continent
Neoproterozoic mobile belts recording subduction, accretion and collision; varied arc and collision plutonisms (635-580 $\mathrm{Ma}$ ); rare late-orogenic events. The main arc extends for more than $750 \mathrm{~km}$, from northeast of João Pessoa, to the east, up to the Pernambuco-Piauí border, to the west

Both Meso-Cenozoic interior and Atlantic marginal basins display important tectonic inheritance from the structural trends of the subprovince

Important tectonic inheritance in Cambro- Ordovician basins; moderate to poor inheritance in Meso-Cenozoic sedimentary covers

Shear zone characterized by melt-assisted intracrystalline dislocation (to the north of the Patos Lineament)
South border of the Patos Lineament marked by low- to medium-grade reactivation, dominated by solid state movements
Several remnants of Cambro-Ordovician volcano- sedimentary basins, associated with anorogenic (granitic) intrusions
Only two or three sparse occurrences of Cambro- Ordovician volcano-sedimentary remnants; Cambro-Ordovician granites unknown up to now

Modest and sparse mineral resources, mainly non- metallic deposits; some $\mathrm{Fe}-\mathrm{Ti} \pm \mathrm{V} \pm \mathrm{Cr} \pm \mathrm{Cu}$ occurrences

mportant and varied metallogenetic provinces of different ages: magnesite, scheelite (W, Mo), Be- Ta, Li pegmatites, P-U, $\mathrm{Au}$, etc.

Crust and lithosphere thicknesses less than those of the Transversal Zone. Moho ca. 31.5 km deep

Crust and lithosphere relatively thicker than those of the Rio Grande do Norte terrane. Moho ca. 32-33 km deep; thickening from the Malta shear zone onwards (northern limit of the keyrogen)

The most magnetic crust of the province; gravity and magnetic sources related to Archean nuclei and to volcano-sedimentary association (+ K- diorites) of the Mataraca-Fronteiras keirogen

Lower crust and lithospheric mantle affected by Meso-

Cenozoic pure and stretching events. Part of the continental margin was developed (Mid- Cretaceous) following transform displacements
Marked gravity zoning in alternating sigmoidal positive and negative NE-SW belts, coinciding with magnetic zoning: dense and magnetic rocks vs. less dense and magnetic rocks

Apparently the Transversal Zone behaved as a barrier against the propagation of the Meso- Cenozoic deformation to the south

*Terranes: SPAB = Piancó-Alto Brígida; RG = Riacho Gravatá; TAP = Alto Pajeú; TAM = Alto Moxotó; RC = Rio Capibaribe; RGN = Rio Grande do Norte. 
1. High-K calc-alkaline magma association;

- Magmatic epidote-bearing high K calc-alkalic plutons (Epidote-bearing HKCA). This association includes a small part of the Conceição-type intrusions as Brejinho, Conceição das Creoulas and Tavares plutons, to which we add the Campina Grande and Serra Redonda plutons (Figs. 5A-5I);

Epidote-free high K-calc-alkalic plutons (Epi.-free HKCA). This association includes the main group of the so-called Itaporanga type intrusions, like Itaporanga, Serra Lagoinha and Bodocó, to which we add the Princeza Isabel and Manaira plutons, among others (Fig. 6a-6C);

2. Magmatic epidote-bearing calc-alkalic and trondhjemitic plutons, which include the major part of the so-called Conceição-type intrusions and Serrita granite types, e.g., Conceição, Emas, Olhos d'Água, Angico Torto, Minador, Verdejante, Boa Ventura, São José do Bonfim, Curral de Cima, Tabira, Riacho do Icó, and Serrita, Salgueiro West, Betânia, respectively (Tab. 2);

3. Ultrapotassic, peralkalic and shoshonitic plutons. Numerous fault-controlled monzonitic, syenitic and granitic intrusions of alkali, ultrapotassic to shoshonitic nature occur in the Transversal Zone. Most of these occurrences are located to the south and southwest of the idealized area of the proposed magmatic arc domain. Some of them (e.g., Teixeira, Palmeira, Salgueiro East) may still belong to the arc development, but it demands further investigations. According to Archanjo et al. (2015), most of these rocks record a tectonic regime transition, from a compressive phase related to plate convergence to a post-collision setting, dominated by extension and transcurrent movements. Usually these kinds of rocks are younger than $600 \mathrm{Ma}$ (Archanjo et al. 2015). Hence, most rocks of this group may be associated (Fig. 4) to within-plate tectonic conditions (post-arc development). Therefore, they will not be discussed any further.

Two age intervals were recognized for rocks of group 1a (epidote-bearing HKCA): The oldest one (650-620 Ma) presents $\mathrm{T}_{\mathrm{DM}}$ ages between 2.1 and $1.01 \mathrm{Ga}$, and $\mathrm{e}_{\mathrm{Nd}(600)}$ values between -3.0 and -16.6. The younger group (590-570 Ma) exhibits Paleoproterozoic $\mathrm{T}_{\mathrm{DM}}$ model ages $(2.0-2.1 \mathrm{Ga})$, and $\mathrm{e}_{\mathrm{Nd}(600)}$ values from -1.7 to -16.02 . This means the possibility of important contribution (contamination) of older crustal material, of previous crustal residence, possibly related to the Paleoproterozoic basement inliers (Figs. 5A-5I).

Geochronological data for the rocks of group $1 \mathrm{~b}$ (epidote-free HKCA) are scarce (590-580 Ma), and cannot be assumed as conclusive. Only in the case of the Itaporanga pluton, $\mathrm{T}_{\mathrm{DM}}$ age of $1.65 \mathrm{Ga}$ and $\mathrm{e}_{\mathrm{Nd}(600)} \approx 9.0$ are available. Given the general geological conditions - such as migmatitic-like features, basement xenoliths and nature of the basement - , the preliminary isotopic data suggest a large degree of crustal contamination of the original magma, as well as other petrological processes. Representative analyses of these plutons plot mostly in the VAG field of Fig. 4, although some plot in the WPG field (Figs. 6A-6C).

Rocks of group 2 (epidote-bearing, calc-alkalic and trondhjemitic), including Conceição and Serrita intrusion-types, were dated 650-610 Ma (mostly U-Pb TIMS ages). $\mathrm{T}_{\mathrm{DM}}$ ages vary between 1.4 and $1.2 \mathrm{Ga}$, and the $\mathrm{e}_{\mathrm{Nd}(600)}$ values are slightly negative, from -2.0 to -4.0 , with just one known positive value up to now. Despite, the few (and not sufficient) number of isotopic data, the indications are pointing out for arc magmatic derivation for these rocks. This is also clear with the plot of their points in the diagram in Fig. 4 (in the VAG field).

\section{MAIN ARGUMENTS FOR THE MAGMATIC ARC PROPOSITION}

The proposition of a continental magmatic arc located in the north-northwest portion of the Transversal Zone is based on various arguments already listed, on observations of different authors within the last 30 years, and on our own geological and geophysical data, connecting well-established scientific facts and some working hypotheses. To become sure about the previous existence of this arc, the present proposal implies additional research and detailed field investigations.

This work will benefit from the critical debate, hopefully motivated by it. Several authors of dissertations and theses (Tab. 2) have highlighted the continental magmatic arc signature of the granites in different geochemical diagrams. However, geotectonic models for the regional context are mostly lacking, although some magmatic arc schemes have been suggested (Cunha 1994, Ferreira 2010, Ferreira et al. 2014). Recent integration of previous ideas further lead to the model that the granitoids were product of a south-directed subduction zone (Brito Neves et al. 2005, Santos et al. 2014, Sial \& Ferreira 2015, Brito Neves et al. 2015b, Brito Neves \& Campos Neto 2016).

Taking into account the geological data discussed before (Tabs. 1 and 2, Figs. 2 and 3), as well as the geophysical data available in the literature (Oliveira 2008, 2013, Santos et al. 2013, Castro et al. 2014, Daly et al. 2015, Lima et al. 2015, Padilha et al. 2016), the following arguments support the magmatic arc model:

1. Juxtaposition of the continental parts of former continental plates (Tab. 3) that are absolutely distinct in terms of composition, structural framework, crustal and lithospheric thickness (according to geophysical parameters, e.g., Lima et al. 2005, Oliveira 2008), as well as tectonic 
evolution and chronology (Tab. 3). The Patos Lineament is now considered a former boundary transform;

2. Opposing gravity anomalies, positive northward and negative southward, as usually recorded in orogenic belts worldwide. The proposed thickening of the southern upper plate (Transversal Zone) is corroborated by deep seismic refraction profiles and magnetotelluric anomalies (Santos et al. 2013, 2014);

3. I-type cordilleran intrusions - sensu Chappel \& White (2001) and similar classifications based on geochemical data (VAG, Pearce et al. 1984; CAG, Maniar \& Piccoli 1989; Hca, Barbarin 1990; etc.) — are aligned following a $750 \mathrm{~km}$ long and 20-140 km wide ca. tectonic zone at the northern part of the Transversal Zone;

4. Probable remnants of oceanic lithosphere are preserved as xenoliths in granodiorite and tonalite intrusions, as indicated by petrologic, geochemical and isotopic data (Ferreira 2010, Ferreira et al. 2014, among others), particularly within the Curral de Cima, Emas and Tavares plutons. Ophiolite remnants are preserved in the greenschists of Cachoeirinha Group, near Bodocó, Pernambuco, though these occurrences still need additional investigation;

5. Preservation of collisional and A-type granites south of the alignment and in back arc compressive zones (Guimarães et al. 2004, Brito Neves et al. 2008, Hollanda et al. 2010, Van Schmus et al. 2011, Lages \& Marinho 2012). The post-arc development of granitic intrusions is younger than $540 \mathrm{Ma}$;

6. In spite of the small amount of data, it is possible to point out coherent geochronological intervals of intrusions: 650-620 Ma (granodiorite, tonalite), 590-570 Ma (porphyritic granite, syenite and shoshonitic granite);

7. Intrusions are preferably emplaced within the CryogenianEdiacaran systems (SPAB) in the north and within the Tonian systems (TAP and RG) in the south, and do not reach the Paleoproterozoic and Archean rocks of TAM, farther south;

8. A forearc basin between the arc and the Patos boundary transform is represented by the RS Fold Belt, comprising distal meta-rhythmites and slates to the north, and proximal (meta)wackes and feldspathic (meta)arenites to the south (Brito Neves \& Campos Neto 2016);

9. At the eastern side of the arc domain (eastward of the meridian $37^{\circ} \mathrm{W}$ ), the structures of the basement of the arc (both supracrustal belts and high-grade terranes) display important thrust faults verging to the north-northwest (affecting the granites of the arc themselves). To the western side of the arc (Fig. 8A, westward of the meridian $38^{\circ}$ ) centrifugal structural vergence, typical of cordilleran arcs, may be observed, comprising: a) compressive domain with essentially north-directed vergence; $b$ ) the south-directed thrusts, verging away from the arc, forming a compressive back-arc zone (Figs. $8 \mathrm{~A}$ and $8 \mathrm{~B}$ );

$10 . \mathrm{Nd}$ values are positive $(\mathrm{ca} .+2.0)$ to slightly negative $(-1.0$ to -7.0$)$. $\mathrm{T}_{\mathrm{DM}}$ model ages range between 1.0 and $1.5 \mathrm{Ga}$, revealing the participation of Tonian and older basement rocks. Occasional older $\mathrm{T}_{\mathrm{DM}}$ values indicate unexposed pre-Mesoproterozoic inliers within the upper plate basement, as recorded along the syenitoid line (Sial 1986) or Teixeira-Terra Nova tectonic zone (Brito Neves et al. 2005);

11. In discriminant geochemical diagrams (Pearce et al. 1984, Pearce 1996, Maniar \& Piccoli 1989), most of these rocks plot in the magmatic arc field (VAG, CAG, Tab. 2), according to the majority of the authors working with these rocks; the epidote-bearing HKCA, epidote-bearing $\mathrm{CA}$ and epidote-bearing shoshonitic $(\mathrm{SH})$ samples plot in the VAG field (Fig. 4A); even epidote-free HKCA (Itaporanga type) plot in the same VAG field (Fig. 4B). The same is true for the felsic dike swarms crosscutting the Salgueiro and Cachoeirinha groups (Figs. 7A-7C);

12. According to recent Gondwana reconstitutions (Pankhurst et al. 2008), it is possible to follow the outlined geological and tectonic patterns into Africa. De Wit et al. (2008) proposed the continuation of the Patos Lineament as the Garoua lineament to the south of Chad Lake and to the south of Libya, as an important suture zone. Van Schmus et al. (2008) refer to juvenile magmatism along the southern part of this lineament, in western Cameroon, southward the Benue trough. Figures $8 \mathrm{~A}$ and $8 \mathrm{~B}$ are the proposed schematic representation of the present and previous (Cryogenian-Ediacaran times) general geologic and geotectonic conditions.

\section{DISCUSSION OF THE RESULTS OBTAINED AND THE NECESSARY NEXT STEPS OF THE RESEARCH}

The plate-tectonic proposal described here is based on field and laboratory observations over many years. It should be taken into consideration as a working hypothesis that should be tested further. Integration of field data, geochemistry and isotopic results indicate the presence of around 90 I-type batholiths and stocks exposed along ca. $750 \mathrm{~km}$ of an orogenic belt, from coastal Paraíba (to the east) to the southeastern border of the Paleozoic Parnaíba Basin (Piauí state, to the west). These batholiths and stocks intruded mainly the rocks of the TAP (Tonian in age) and the Piancó-Alto Brígida fold belt (Ediacaran in age), but not exclusively. These rocks display clear magmatic arc-type geochemical 
and isotopic signatures, and bear some local evidence of oceanic crust basalt relics.

There are remarkable geological, geochemical, and geophysical differences between the inferred lower plate, the northern subprovince, and the upper plate, represented by the Transversal Zone, which interacted during the magmatic arc construction. The former plates are presently separated by an intracontinental plate boundary transform, namely the Patos Lineament.

However, there is still a great deal of research to be done, and many scientific questions to be answered in order to provide additional support for the magmatic arc hypothesis. First and foremost, 1: 100,000-scale geological mapping should be continued, including updating of older editions. Geophysical surveys should grow in scale, as well as focus on the magmatic arc model. Petrological investigation and associated isotopic studies should be improved, including Lu-Hf isotopic determinations, consorted with $\mathrm{U}-\mathrm{Pb}$ research. There are still many plutons and stocks to be better investigated. Special attention should be directed to the felsic calc-alkaline dikes and sills crosscutting the supracrustals of the Salgueiro-Cachoeirinha group of the Piancó Alto Brígida belt system. Due to their geochemical signatures (Brito 2014), they probably are related to subduction processes.

A

Foreland

Keyrogen

Forearc Arc Plutonism Back Arc Domains

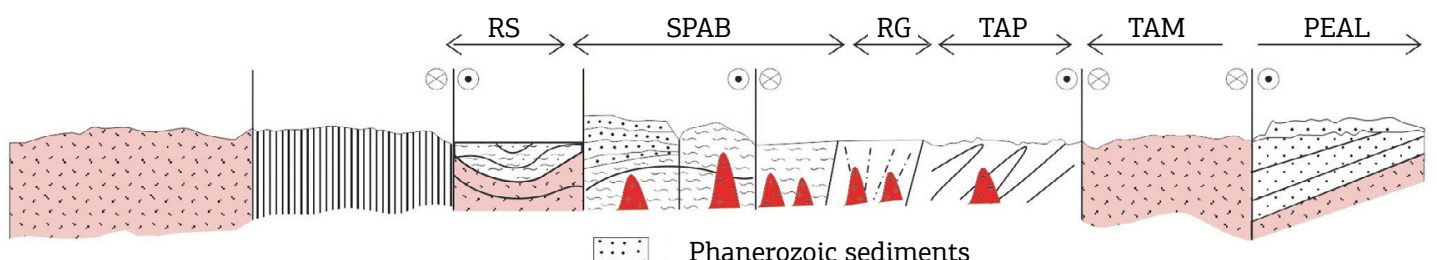

Pernambuco - Alagoas Superterrane (PEAL)

$\because \therefore$ Alto Moxotó Terrane (TAM)

Foreland (Rio Grande do Norte Terrane)

Rio Salgado Belt (RS)

Pianco-Alto Brígida System (PAB)

Riacho Gravatá Complex (RG)

Alto Pajeú Terrane (TAP)

B

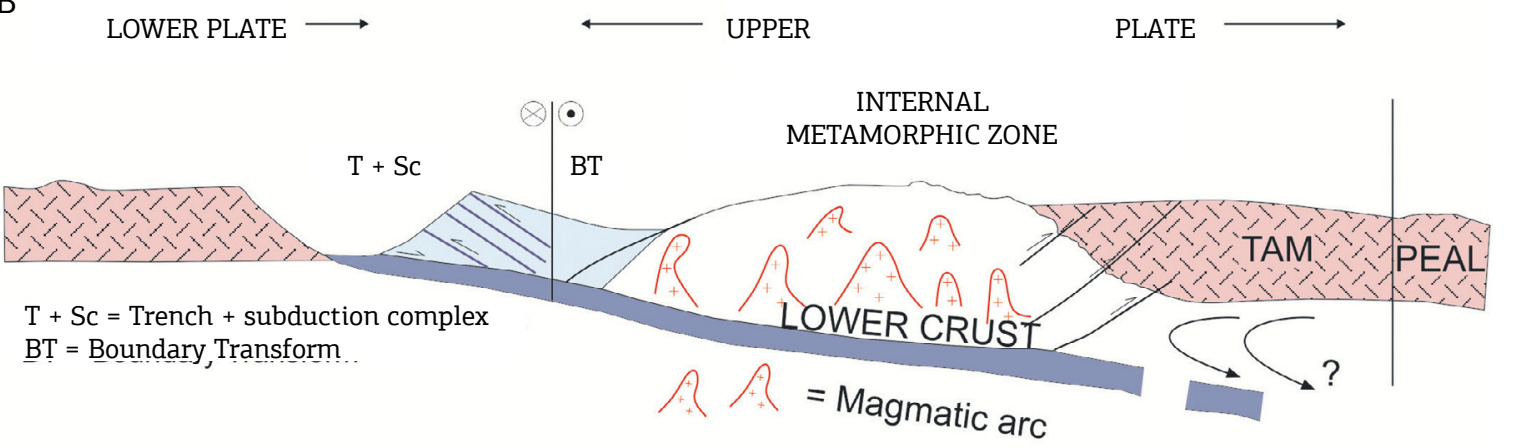

TAM = Alto Moxotó Terranes

PEAL = Pernambuco Alagoas Terranes

Back Arc Terranes and thrusts

Figure 8. (A) General N-S geological section from the foreland (Rio Grande do Norte Terrane) to the back-arc domains (Alto Moxotó - TAM, and probably PEAL terranes), passing through different petrotectonic environments: keirogen, boundary transform (Patos Lineament), forearc basin (Rio Salgado Belt), Neoproterozoic belts pierced by the arc plutonism, and the back arc domains (TAM, PEAL); (B) proposed preliminary (hypothetical) draft of the plate-interaction events during Late Cryogenian-Early Edicaran times (Tab. 3), highlighting the geological and geophysical differences between the two plate segments, presently exposed. 


\section{Alternative models}

Up to now, there has not been an alternative model for this series of Cryogenian-early Ediacaran stocks and batholiths placed at the northern part of the Transversal Zone. Most of the authors mentioned in this paper (especially those mentioned in Tab. 2) have, in some way, indicated plate interactions as a driver for arc construction. Thus, we here present an integration of local models, connecting them to the available geological, geochemical and geophysical data.

Nevertheless, there are some few authors who argue against a plate-tectonic accretionary process for the Meso and Neoproterozoic evolution of the Borborema Province (Neves \& Alcantara 2010, Neves 2011) According to these researchers, the Borborema Province has behaved as an intracratonic setting since the late Paleoproterozoic. This means that all fold belts and granitic plutonism were the product of lithosphere extension without any formation of oceanic crust, followed by compression due to far-field stresses. A synthesis of the main ideas of this group of research was recently published by Neves (2015).

According to our point of view (with all due respect), these authors did not present, up to now, the necessary constraints, nor sufficient arguments to deny all the facts pointing out to subduction processes.

Thus, we hope that this contribution will lead to new investigations aimed at overcoming possible contradictions and disagreements and point the way forward for understanding the evolution of Borborema Province.

\section{ACKNOWLEDGMENTS}

This work was possible thanks to the discussions with and invaluable help of many researchers, particularly Gorki Mariano, Valderez Pinto Ferreira, Alcides Nóbrega Sial, Ignez Pinho Guimarães, Ricardo José Ribeiro Pessoa, Vladimir Medeiros, Roberto Gusmão Oliveira and Maria de Fátima Lyra Brito. Financial support was provided by National Counsel of Technological and Scientific Development (CNPq), through National Institute of Science and Technology (INCT) Estudos Tectônicos, and by Fundaçáo de Amparo à Pesquisa do Estado de Sáo Paulo (FAPESP) (Research Project 2013/09484-0). BBBN and RAF acknowledge CNPq research grants.

\section{REFERENCES}

Almeida C.N., Guimarães I.P., Silva Filho A.F. 2002. Petrogênese de rochas plutônicas félsicas e máficas na Província Borborema, NE do Brasil: o complexo cálcio-alcalino de Alto-K de Campina Grande. Revista Brasileira de Geociências, 32:205-216.

Almeida F.F.M., Leonardos Junior O.H., Valença J. 1967. Granitic Rocks of Northeast South America. In: International Symposium on Granites, Northeast Brazil Special Publication. Anais... IUGS/ UNESCO, Recife, 37p.

Archanjo C.J., Hollanda M.H.B.M., Vasconcelos P.M., Liu D. 2015. Geochonology (U-PB, AR/AR) and tectonic setting of the peralkalineshoshonitic magmatism of the Teixeira-Terra Nova Domain (Central Borborema Province, NE Brazil) - PT.066. In: Hutton Symposium, 8., Florianópolis. CD-ROM.

Archanjo C.J., Viegas L.G., Freimann M., Hollanda M.H.B.M. 2013. O Lineamento Patos: estrutura e evolução. In: Simpósio de Geologia do Nordeste, 25., Gravatá-Pernambuco. CD-ROM.

Barbarin B. 1990. Granitoids: main petrogenetic classification in relation to origin and tectonic setting. Geological Journal, 25:227-238.

Barriga V.M.F. 1983. Petrologia e geoquímica das rochas plutônicas de Conceição-Itaporanga (PB). Dissertação de Mestrado, Centro de Ciências Geofísicas e Geológicas, Universidade Federal do Pará, Belém, 146p

Brito M.F.L. 2014. Metavulcânicas ácidas do Complexo Salgueiro: caracterização e comparação com aquelas do Complexo Riacho Gravatá e Grupo Cachoeirinha, Zona Transversal, Província Borborema, NE Brasil. In: Congresso Brasileiro de Geologia, 47., Salvador. Anais... Salvador: SBG, p.121.

Brito Neves B.B. \& Campos Neto M.C. 2016. A faixa de d obramentos do Rio Salgado, norte-noroeste da Zona Transversal Província Borborema (PB-CE). Geologia USP Série Científica, 16 (3):317. doi: 10.11606/issn.2316-9095.
Brito Neves B.B., Mantovani M.S.M., Moraes C.F., Sigolo J.B. 2008. As anomalias geológicas e geofísicas ao norte de Itapororoca (PB), folha Guarabira. Revista Brasileira de Geociências, 38(1):1-23.

Brito Neves B.B., Passarelli C.R., Basei M.A.S., Santos E.J. 2003. Idades U-Pb em zircão de alguns granitos clássicos da Província Borborema. Revista do Instituto de Geociências, 3:25-38.

Brito Neves B.B., Santos E.J., Fuck R.A. 2015a. Caracterização do Lineamento Patos como uma "boundary transform" intracontinental. In: Simpósio Nacional de Estudos Tectônicos, 15., Vitória. Anais... Vitória, Brazil. CD-ROM.

Brito Neves B.B., Santos E.J., Fuck R.A. 2015b. An Early Ediacaran magmatic arc at the northernmost part of the Transversal Zone The Central Domain of the Borborema Province, Northeast of South America. In: Hutton Symposium, 8., Florianópolis. CD-ROM.

Brito Neves B.B., Santos E.J., Van Schmus W.R. 2000. Tectonic History of the Borborema Province. In: Cordani U.G., Milani E.J., Thomaz Filho A., Almeida D.A. (eds.). Tectonic Evolution of South America. 31th Interntational Geological Congress, Rio de Janeiro, p.151-182.

Brito Neves B.B., Van Schmus W.R., Kozuch M., Santos E.J., Petronilho L. 2005. A Zona Tectônica Teixeira Terra Nova - ZTTTN fundamentos da geologia regional e isotópica. Revista do Instituto de Geociências, 5(1):57-80.

Castro D., Fuck R.A.D., Phillips J.D., Vidotti R.M., Bezerra F.H., Dantas E.L. 2014. Crustal structure beneath the Paleozoic Parnaíba Basin, revealed by airborne gravimetry and magnetic data, NE Brazil. Tectophysics, 614:128-145.

Chappell B.W. \& White A.J.R. 2001. Two contrasting granite types: 25 years late. Australian Journal of Earth Sciences, 48:489-499. 
Cordani U.G., Pimentel M.M., Araújo C.E.G., Fuck R.A. 2013. The significance of the Transbrasiliano-Kandi corridor for the amalgamation of West Gondwana. Brazilian Journal of Geology, 43(3):583-597. doi: 10.5327/Z2317-48892013000300012.

Cunha M.A.L. 1994. Petrologia, geoquimica e profundidade de posicionamento dos stocks granodioríticos-tonalíticos de Boa Ventura, Conceição e Pedra Branca, Paraiba, Nordeste do Brasil. Dissertação de Mestrado, Universidade Federal de Pernambuco, Technological Center, 160p.

Daly M.C., Andrade V., Basrousse C.A., Costa R., McDowell K. Piggott N., Poole A.J. 2015. Brasiliano crustal structure and tectonic setting of the Parnaíba basin of NE Brazil: results of a deep seismic reflection profile. Tectonics, 33:2102-2120. doi: 10.1002/2014TC003632

Delgado I.M. (coord.). 2003. Geotectônica do Escudo Atlântico. In: Bizzi L.A., Schobbenhaus C., Vidotti R.M., Gonçalves J.H. (eds.). Geologia, Tectônica e Recursos Minerais do Brasil. Texto, Mapas \& SIG. Brasília, CPRM-Serviço Geológico do Brasil, p.227-334.

De Wit M.J., Stankiewicz I., Reeves C. 2008. Restoring Pan-AfricanBrasiliano connections: more Gondwana control, less trans-Atlantic corruption. In: Pankhurst R.J., Trouw R.A.J., Brito Neves B.B., De Wit M.J. (eds.). West Gondwana: Pre-Cenozoic correlations across the South Atlantic region. The Geological Society of London, Special Publication, 294:399-422.

Ferreira V.P. 2010. Plutonismo saturado a supersaturado na Zona Transversal, porção leste da Província. Borborema; revisão petrológica, geoquímica e isotópica. Full Professor thesis, Universidade Federal de Pernambuco, Technological Center, 170p.

Ferreira V.P., Sial A.N. 1993. Mica-pyroxenite as probable source for ultrapotassic magmas in Northeastern Brazil: geochemistry and oxygen isotopes. In: Magma workshop - Magmatismo Granítico e Mineralizações Associadas, Academia Brasileira de Ciências, Rio de Janeiro. Resumos Expandidos, p.18-21.

Ferreira V.P., Sial A.N., Pimentel M.M., Moura C.A.V. 2004. Intermediate to acidic magmatism and crustal evolution in the Transversal Zone, Northeastern Brazil. In: Mantesso-Neto V., Bartorelli A., Carneiro C.D.R., Brito Neves B.B. (eds.). Geologia do Continente Sul-Americano - Evolução da Obra de Fernando Flávio Marques de Almeida. Beca, São Paulo, p.189-201.

Ferreira V.P., Sial A.N., Pimentel M.M., Armstrong R., Spicuzza M.J., Guimarães I.P., Silva Filho, A.F. 2011. Contrasting sources and P-T crystallization conditions of epidote-bearing granitic rocks, northeastern Brazil: $\mathrm{O}, \mathrm{Sr}$, and $\mathrm{Nd}$ isotopes. Lithos, 121:189-201.

Ferreira V.P., Valley J., Sial A.N., Pessoa R.J., Spicuzza M. 2014 Oceanic crust source-derived Tavares high-K Quartz Monozonite, Borborema Province, NE Brazil: geochemical and isotopic evidence. In: Brazilian Geological Congress, 47., Salvador. Anais... Salvador: Núcleo Bahia da SBG, p.285.

Fetter A.H., Santos T.J.S., Van Schmus W.R.V., Hackspacher P.C., Brito Neves B.B., Arthaud M.H., Nogueira Neto J.A., Wernick E. 2003. Evidence for Neoproterozoic continental arc magmatism in the Santa Quitéria batholith of Ceará State, NW Borborema Province, NE Brazil: Implications for the assembly of West Gondwana. Gondwana Research, 6(2):265-273.

Goist T.O. 1989. Petrology and geochemistry of the Emas pluton Northeastern Brazil. Master Dissertation, Universidade Federal de Pernambuco, Technological Center, 157p.

Guimarães I.P., Silva Filho A.F., Almeida C.N., Van Schmus W.R., Melo S.C., Melo E.B. 2004. Brasiliano (Pan-African) granitic magmatism in the Pajeú-Paraiba belt, Northeast Brazil: an isotopic and geochronological approach. Precambrian Research, 135:23-53.
Hollanda M.H.B.M. Archanjo C.J., Souza L.C., Armstrong R., Vasconcelos P.M. 2010. Cambrian mafic to felsic magmatism and its connections with transcurrent shear zones of the Borborema Province (NE Brazil): implications for the late assembly of the West Gondwana. Precambrian Research, 178:1-4. doi: 10.1016/j. precamres.2009.12.004.

Lages G.A., Marinho M.S. 2012. Folha Boqueirão SB24Z-D-III Escala 1:100 000. Estado da Paraíba. Brasília. CPRM - Serviço Geológico do Brasil. Disponível em: <http://geobank.cprm.gov.br/>

Lima M.V.A.G., Berrocal J., Soares J.E.P., Fuck R.A. 2015. Deep seismic refraction experiment in Northeast Brazil: New constraints for Borborema Province evolution. Journal of South American Earth 14 Sciences, 58:335-349. doi: 10.1016/j.jsames.2014.10.007.

Maniar P.D., Piccoli P.M. 1989. Tectonic discrimination of granitoids. Geological Society of America Bulletin, 101:635-643.

Mariano G. 1989. Magma mixing origin of Potassic Calk-alkaline pluton: the Itaporanga Batholith, state of Paraiba, Northeastern Brazil. Master dissertation, University of Georgia, Athens, 180p.

Mariano G., Sial A.N. 1990. Coexistence and mixing of magmas in the late precambrian Itaporanga Batholith, State of Paraíba, Northeastern Brazil. Revista Brasileira de Geociências, 20:101-110.

Mariano G., Sial A.N. 1993. High -K calc-alkalic vs. Shoshonitic granitic magmatism in northeastern Brazil. Anais da Academia Brasileira de Ciências, 65(supl):119-130.

Mariano G., Sial A.N., Herz N. 1990. Oxygen isotope geochemistry of a potassic porphyritic calc-alkaline composite pluton: the Itaporanga Batholith, state of Paraíba, Northeastern Brazil. Revista Brasileira de Geociências, 20(1-4):159-164.

McMurry J. 1995. Mesonorm-based rock names for the Bodocó Pluton, Northeastern Brazil, and other metaluminous megacrystic rocks. Anais da Academia Brasileira de Ciências, 67:289-300.

McMurry J. 2001. Crystal accumulation and shearing in a Megacryst Quartz Monzonite: Bodocó Pluton, Northeastern Brazil. Journal of Petrology, 42(2):251-276.

Nédeléc A., Bouchez J.L. 2011. Petrologie des Granites. Vuibert, Societé Geologique de France, 237p.

Neves S.P. 1986. Petrologia e geoquímica dos stocks graníticos de Serrita, Pernambuco. Revista Brasileira de Geociências, 16(1):86-94.

Neves S.P. 2011. Atlantica revisited: new data and thoughts on the formation and evolution of a long-lived continent. International Geology Review, 53(11-12):1377-1391. doi: http://dx.doi.org/10.108 $0 / 002068142010.527676$

Neves S.P. 2015. Constraints from zircon geochronology on the tectonic evolution of the Borborema Province (NE brazil): widespread intracontinental Neoproterozoic reworking of a Paleoproterozoic accretionary orogen. Journal of South American Earth Sciences,58:150-164.

Neves S.P. \& Alcantara V.C. 2010. Geochemistry of orthogneisses and metasedimentary rocks across a proposed terrane boundary in the Central Domain of Borborema Province, NE Brazil: Geodynamic implications. Journal of South American Earth Sciences, 29(2):498511. http://dx.doi.org/10.1016/j.jsames.2009.08.002.

Oliveira E.P., Windley B.F., Araújo M.N.C. 2010. The Neoproterozoic Sergipano orogenic belt, NE Brazil: a complete plate tectonic cycle in western Gondwana. Precambrian Research, 181(1-4):64-84. doi: 10.1016/.precamres.2010.05.014

Oliveira R.G. 2008. Arcabouço geofísico, isostasia e causas do magmatismo cenozóico da Província Borborema e de sua margem continental (Nordeste do Brasil). PhD thesis, Centro de Ciências Exatas e da Terra, Universidade Federal do Rio Grande do Norte, 411p. 
Oliveira R.G. 2013. Arcabouço geofísico da Província Borborema: novos dados e novas perspectivas. In: Simpósio de Geologia do Nordeste, 25., Gravatá, Pernambuco. CD-ROM.

Padilha A.L., Vitorello I., Pádua M.B., Fuck R.A. 2016. Deep magnetotelluric signatures of the early Neoproterozoic Cariris Velhos tectonic event within the Transversal sub-province of the Borborema Province, NE Brazil. Precambrian Research, 275:70-83.

Pankhurst R.J., Trouw R.A.J., Brito Neves B.B., De Wit M.J. 2008. West Gondwana: Pre-Cenozoic Correlations Across South Atlantic Region. The Geological Society of London, Special Publication, 294, 432p.

Pessoa R.J.R. 2001. Mecanismos de alojamento e construção do batólito granítico neoproterozoico de Tavares, Estado da Paraiba - Nordeste do Brasil. Tese de Doutorado, Centro de Tecnologia e Geociências, Universidade Federal de Pernambuco, Recife, 218p.

Pearce J.A., Harris N.B.W., Tindle A.G. 1984. Trace element discrimination diagrams for the tectonic interpretation of granitic rocks. Journal of Petrology, 25(4):956-983. doi: 10.1093/ petrology/25.4.956.

Pearce J.A. 1996. Sources and settings of granitic rocks. Episodes, 19(4):120-125.

Pitcher W.S. 1983. Granite type and tectonic environment. In: Hsu K. (ed.). Mountain Building Processes. Academic Press, p.19-40.

Santos A.C.L., Padilha A.L., Fuck R.A., Pires A.C.B., Vitorello I., Pádua M.B. 2014. Deep structure of a stretched lithosphere: magnetotelluric imaging of the southeastern Borborema P rovince, NE Brazil. Tectonophysics, 610:29-50.

Santos A.C.L., Padilha A.L., Fuck R.A., Pires A.C.B., Vitorello I., Pádua M.B. 2013. Magnetotelluric imaging of the southeastern Borborema Province, NE Brazil. In: International Congress of the Brazilian Geological Society, 23., 1-6.

Santos E.J., Brito Neves B.B. 1984. Província Borborema. In: Almeida F.F.M. \& Hasui Y. (eds). O Pré-Cambriano do Brasil. São Paulo, Blücher, p.123-204.

Santos E.J., Coutinho M.G.N., Costa M.P.A., Ramalho R. 1984. A Região de Dobramentos Nordeste e a Bacia do Parnaíba, incluindo o cráton de São Luis e as Bacias Marginais. In: Schobbenhaus C., Campos D.A., Derze G.R., Asmus H.E. (eds.) Geologia do Brasil Texto explicativo do mapa geológico do Brasil e da área oceânica adjacente incluindo depósitos minerais. Brasília, Ministério das Minas e Energia, Departamento Nacional da Produção Mineral, p.131-189.

Santos E.J., Medeiros V.C. 1999. Constraints from granitic plutonism on proterozoic crustal growth of the Transverse Zone, Broborema Province, NE Brazil. Revista Brasileira de Geociências, 29(1):73-84.

Santos E.J., Santos L.C.M.L., Brito Neves B.B. 2014. Acresção e dispersão de terrenos na Província Borborema, NE do Brasil. In: Congresso Brasileiro de Geologia, 47., Salvador. Anais... Salvador: SBG, p.121. CD-ROM.
Santos E.J., Van Schmus W.R., Kozuch M., Brito Neves B.B. 2010. The Cariris Velhos tectonic event in Northeast Brazil. Journal of South American Earth Sciences, 29(1):61-76. doi: 10.1016/j. jsames.2009.07.003.

Santos T.J.S., Garcia M.G.M., Amaral W.S., Caby R., Wernick E., Arthaud M.H., Dantas E.L., Santosh M. 2009. Relics of eclogite facies assemblage in the Ceará Central domain, NW Borborema Province, NE Brazil: implications for the assembly of West Gondwana. Gondwana Research, 15:454-470.

Sial A.N. 1993. Contrasting metaluminous magmatic epidotebearing granitic. Suites from two Precambrian fold belts. Anais da Academia. Brasileira de Ciências, 65(Suplemento 1):141-162.

Sial A.N. 1986. Granite types in Northeast Brazil: current knowledge. Revista Brasileira de Geociências, 16(1):54-72.

Sial A.N. 1987. Granitic rocks of Northeast Brazil. In: International Symposium on Granites and Associated Mineralizations, 1., Salvador. Extended Abstracts, Salvador: SGM. p.61-69.

Sial A.N. \& Ferreira V.P. 1985. Proterozoic granitoids of Northeast Brazil, Central Pernambuco and Paraíba states. Field trip guide. In: Workshop on granites and associated mineralizations, CaruaruPE. Anais... Natural Council for Scientific Development-CNPq, 19p.

Sial A.N. \& Ferreira V.P. 2015. Magma association in Ediacaran granitoids of the Cachoeirinha-Salgueiro and Alto Pajeú terranes, northeastern Brazil: forty years of studies. Journal of South American Earth Sciences, 68:113-133. doi: 10.1016/j.jsames.2015.10.005.

Sial A.N., Ferreira V.P., Santos E.J. 1997. Magmatic epidotebearing granitoids and ultrapotassic magmatism of the Borborema Province, Northeast Brazil. In: International Symposium on Granites and Associated Mineralizations, 2.. Excursion Guides, p. 33-54.

Sial A.N., Vasconcelos P.M., Ferreira V.P., Pessoa R.J.R., Brasilino R.G., Moraes Neto J. 2008. Geochronological and mineralogical constraints of depth of emplacement and ascension rates of epidote-bearing magmas form Northeastern Brazil. Lithos, 105:225-238.

Torres H.H.F. 2001. Petrologia e geoguímica do batólito cálcio-alcalino de alto-K de Brejinho, domínio da Zona Transversal, Província Borborema, NE do Brasil. Tese de Doutorado, Universidade de Pernambuco, 185p.

Van Schmus W.R., Kozuch M., Brito Neves B.B. 2011. Precambrian history of the Zona Transversal of the Borborema Province: insights from Sm-Nd and U-Pb geochronology. Journal of South American Earth Sciences, 31:227-252.

Van Schmus W.R., Oliveira E.P., Silva Filho A.F., Toteu S.F., Guimarães I.P. 2008. Proterozoic links between Borborema Province, NE Brazil and its correlation with Central Africa fold belt. In: Pankhurst R.J., Trouw R.A.J., Brito Neves B.B., De Wit M.J. (eds.) West Gondwana. Pre-Cenozoic correlation across the South Atlantic Region. The Geological Society of London, Special Publication, 294, p.69-100.

Available at wwww.sbgeo.org.br 